تطوير ممارسات المشرفين الإداريين في وزارة التربية والتعليم بسلطنة عمان في ضوء مبادئ

\title{
الجودة الشاملة
}

\author{
زايد بن خليفة بن محمد المقبالي \\ قسم الأصول والإدارة التربوية- كلية التربية- جامعة السلطان قابوس- سلطنة عملاندان \\ zayd.almuqbali@moe.om
}

الملخخص:

هدفت هذه الدراسة تطوير ممارسات المشرفين الإداريين في وزارة التربية والتعليم بسلطنة عمان في ضوء مبادئ التئ الجواد التودة الشاملة، ولتحقيق

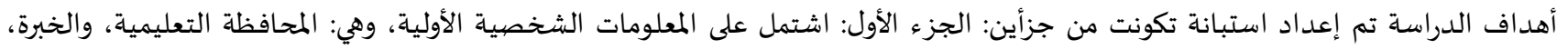

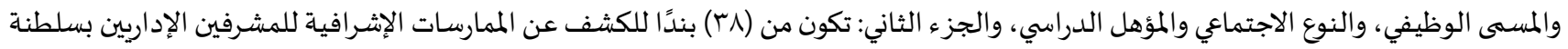

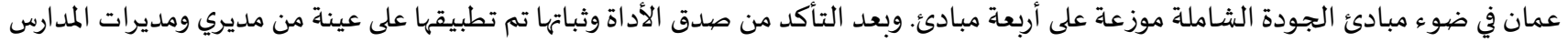

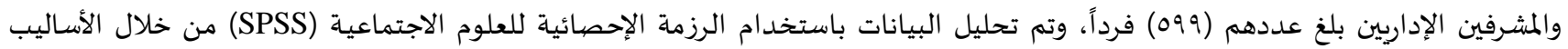

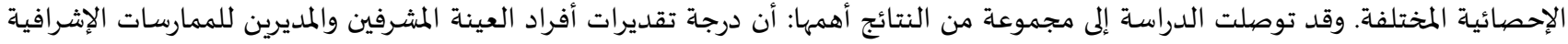

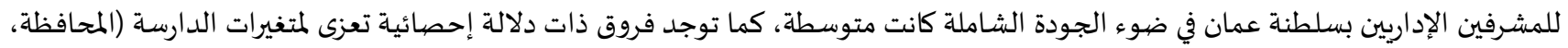

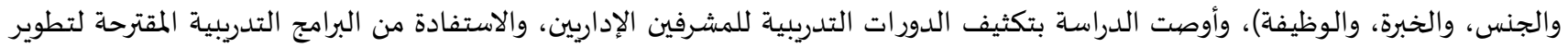

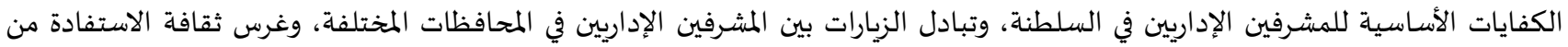
الأبحاث والدراسات المختلفة.

الكلمات المفتاحية: المشرفين، سلطنة عُمان، الجودة الشاملة.

\section{(a) (1)}

المقدمة:

ظهرت في الآونة الأخيرة العديد من التطورات على مختلف الأصعدة، سواء في القطاعات التربوية أو الإعلامية أو السياسية وغيرها. ونتيجة

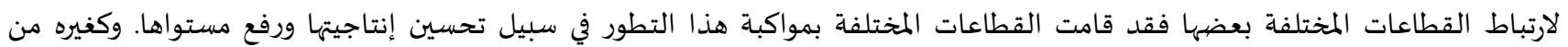

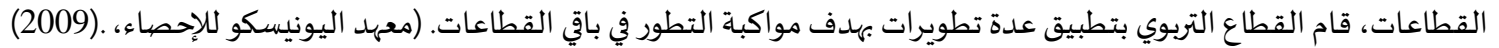

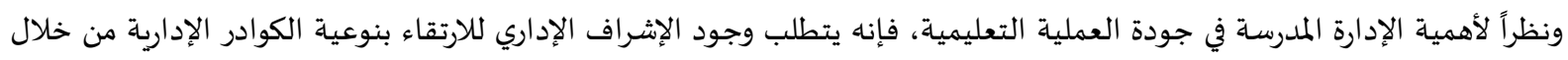

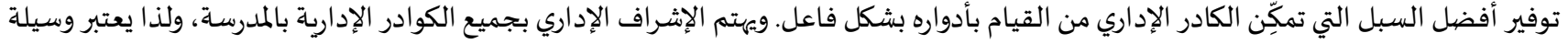

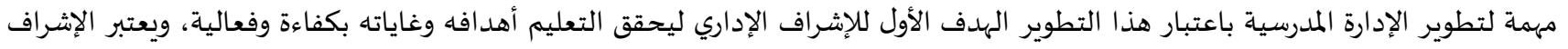

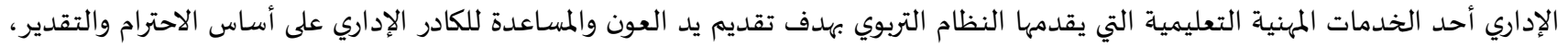

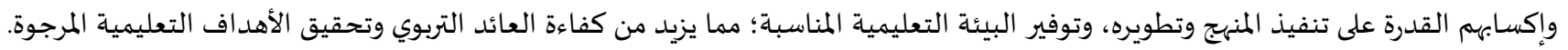

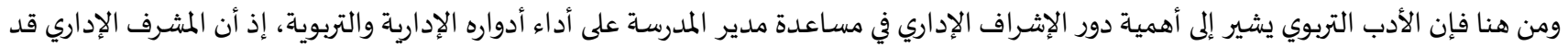

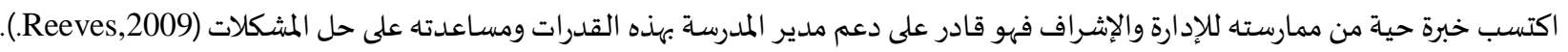

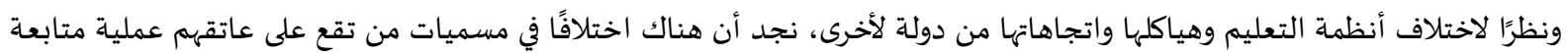

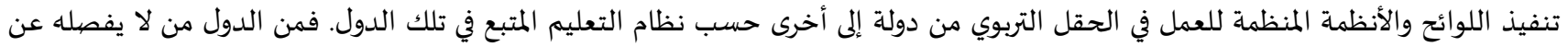

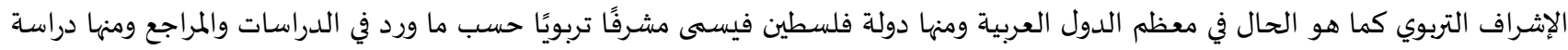

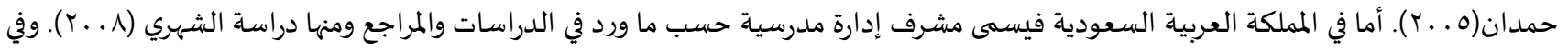

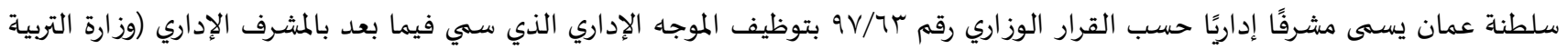

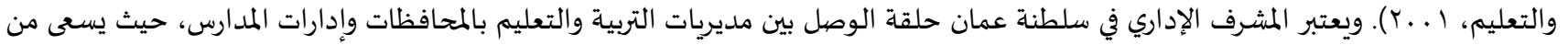

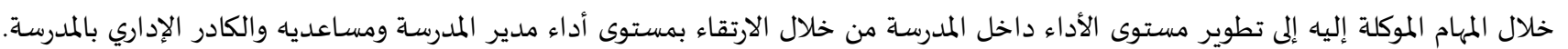


فمدير المدرسة يحتاج إلى من يوجهاه ويرشده ويشرف عليه حتى يتقن أساليب الإدارة الناجحة مع المعلمين والطلاب والمجتمع ويحقق الأهداف التي

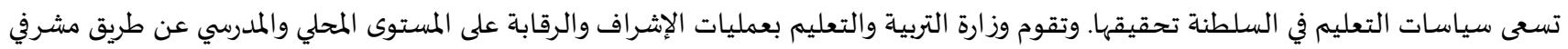

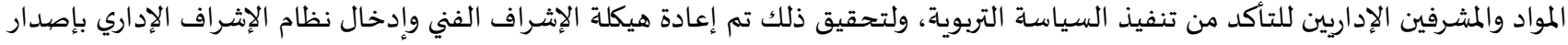

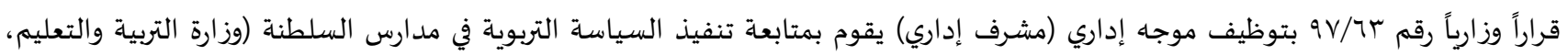

( $($...

وتعتبر مبادئ الجودة الشاملة من الأساليب التي دخلت حديثاً إلى مجال التربية بعد أن أثبتت نجاحها في مجالات أخرى، وتسعى الجودة الجرائ

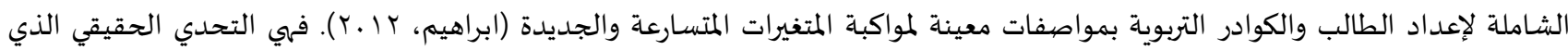

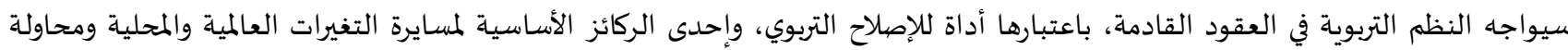

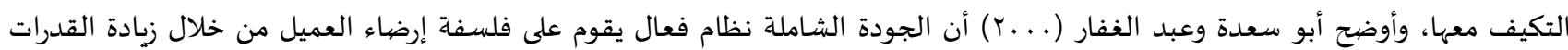

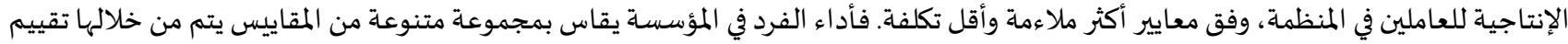

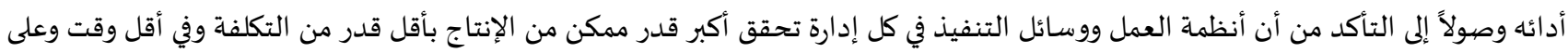

مستوى مناسب من الجودة. Mosimann and Dussault, 2007)

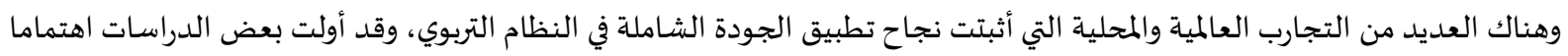

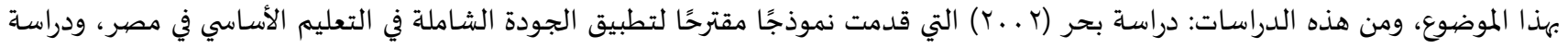

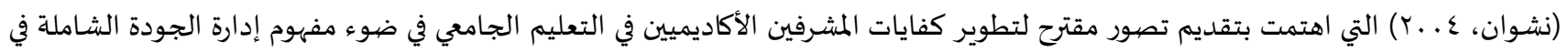

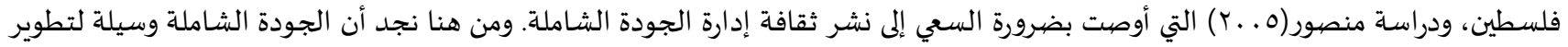

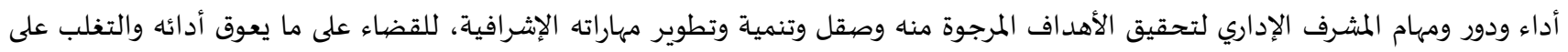

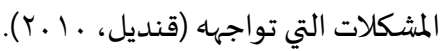

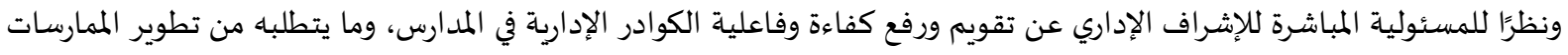

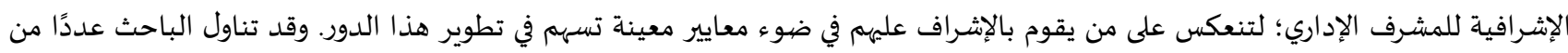

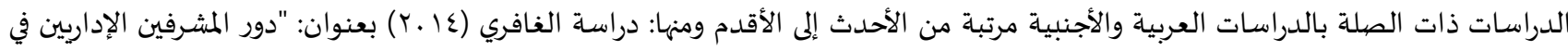

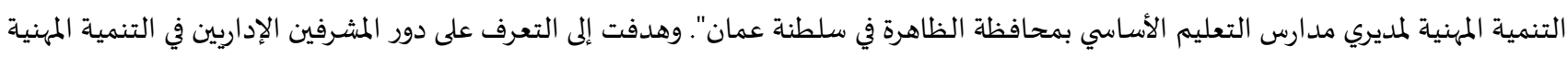

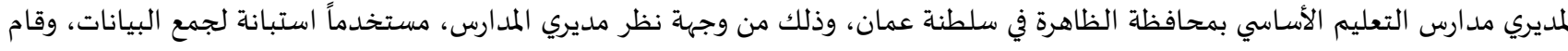

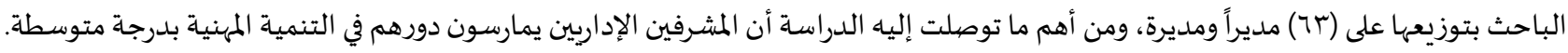

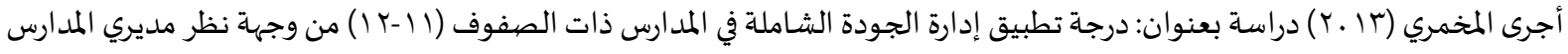

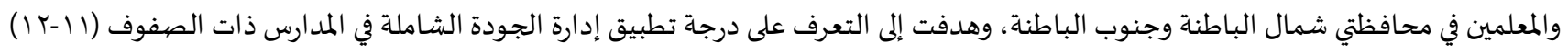

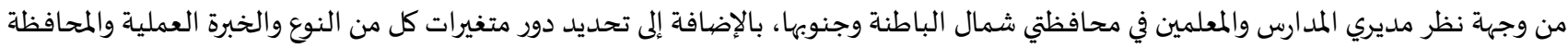

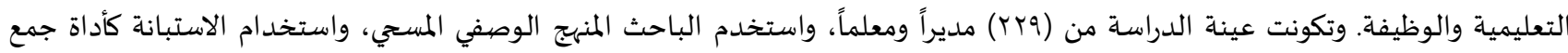

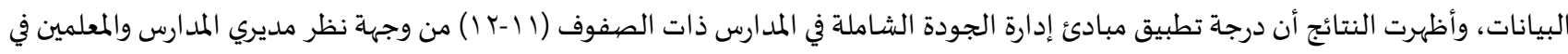

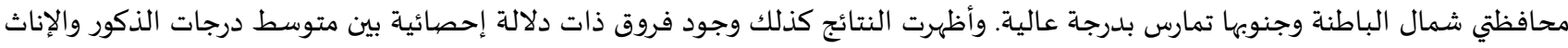
لصالح الإناث.

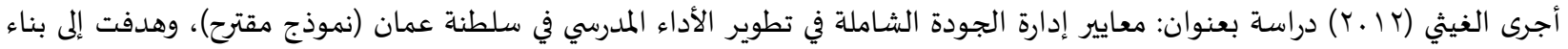

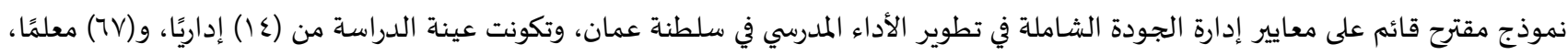

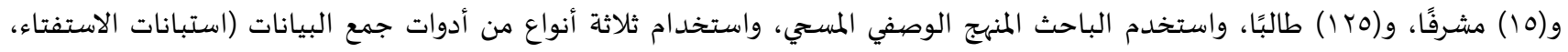

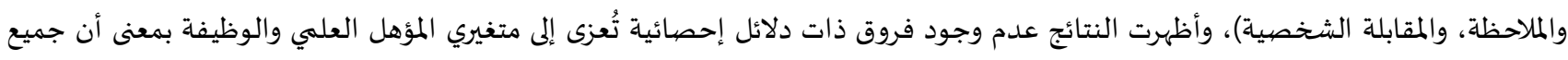

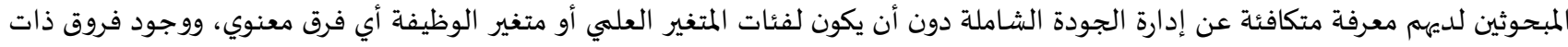

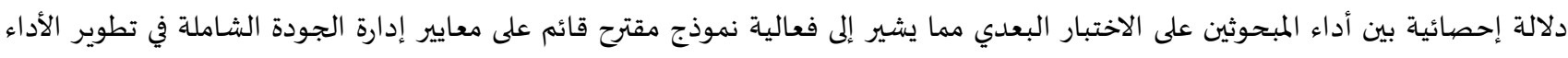

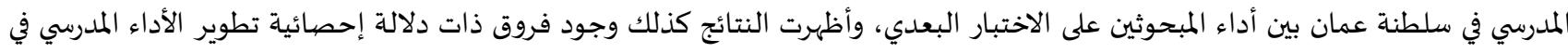

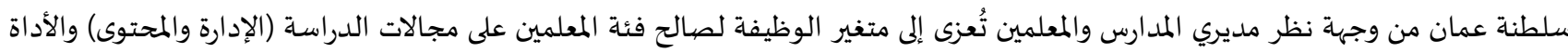

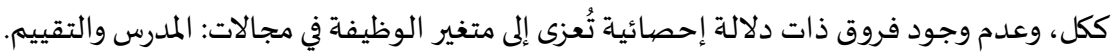


دراسة الحبسي (1 إY) بعنوان: "درجة فاعلية المشرف الإداري في تطوير أداء مديري مدارس التعليم الأساسي ومساعديهم بمحافظة مسقط"

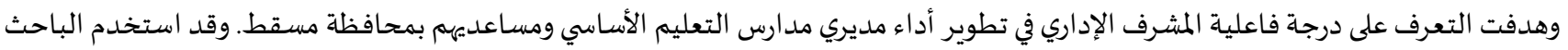

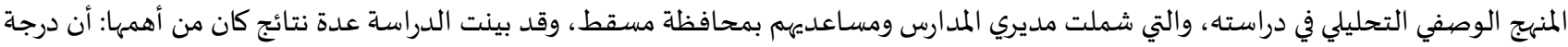
فاعلية المشرف الإداري في تطوير أداء مديري مدارس التعليم الأساسي ومساعديهم من وجهة نظر مديري مدارس التعليم الأساسي ومساعديهم بمحافظة مسقط في سلطنة عمان درجة متوسطة. أما دراسة الرقمي (1 ا ب) بعنوان: "مصادر ضغوط العمل لدى المشرفين الإداريين بسلطنة عمان" هدفت إلى التعرف على أهم مصادر ضغوط

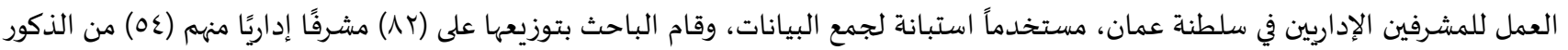

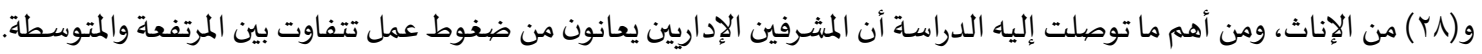

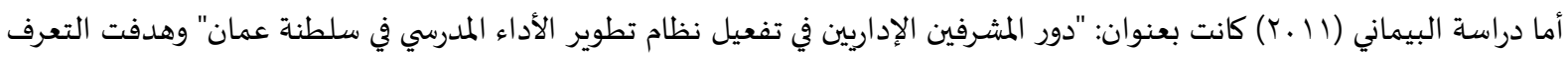
على دور المشرفين الإداريين في تفعيل نظام تطوير الأداء المدرسي في مدارس التعليم الأساسي بسلطنة عمان من وجهة نظر مديري المدارس ومساعديهم.

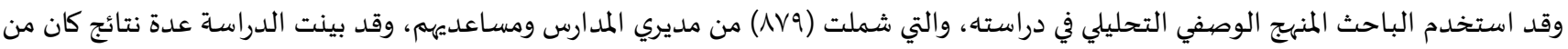
أهمها: أن المشرفين الإداريين يمارسون أدوارهم في تفعيل نظام تطوير الأداء المدرسي بدرجة متوسطة من وجهة نظر مديري مدارس التعليم الأساسي

ومساعديهم بسلطنة عمان.

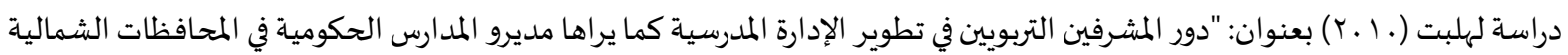

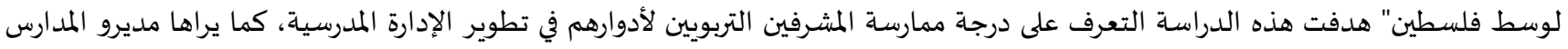
الحكومية في المحافظات الشمالية لوسط فلسطين، بالإضافة إلى بيان أثر متغيرات الدراسـة: الجنس، ونوع المدرسة، والخبرة، والمؤهل العلمي في آراء

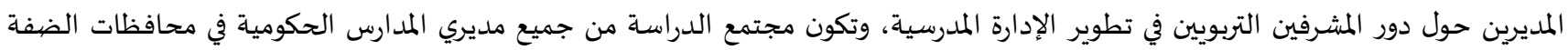

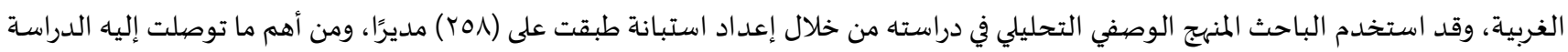

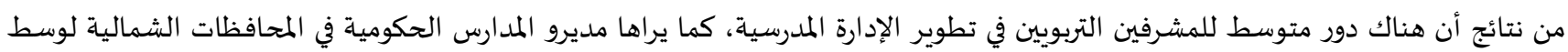
فلسـين. أجرى الراشدي (9 . . ب) دراسـة بعنوان: تطبيق إدارة الجودة لدراسة مشاكل تعامل المعلم مع المستجدات التربوية، وهدفت إلى تسليط الضوء

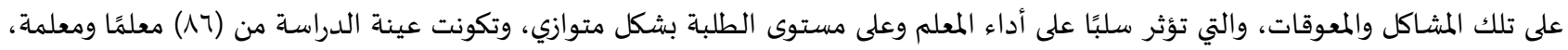
واستخدم الباحث المنهج الوصفي، واستخدم المقابلات الشخصية والاستبانة كأدوات دراسة، وأظهرت النتائج وجود انخفاض في مستوى وعي المعلمين

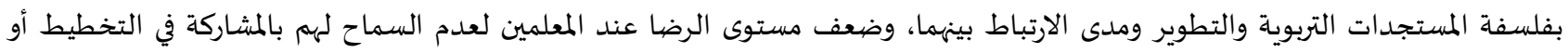

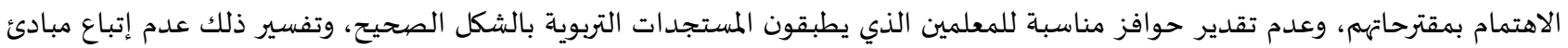
إدارة الجودة الشاملة. دراسة الشهري (1 . . ب) بعنوان: "واقع الكفايات المهنية لمشرفي الإدارة المدرسية" هدفت الدراسة إلى تحديد الكفايات المهنية لمشرفي الإدارة المدرسية، والتعرف على درجة أهمية توفرها لديهم ودرجة ممارستهم لها من وجهة نظر مديري المدارس ومشرفي الإدارة المدرسية أنفسههم، وتحديد

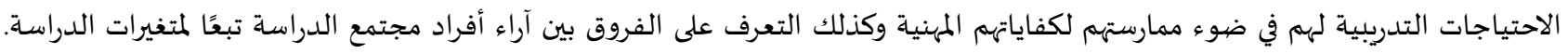

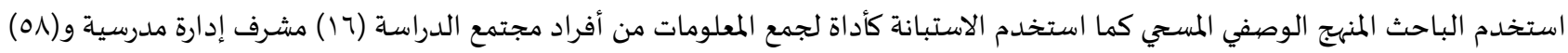

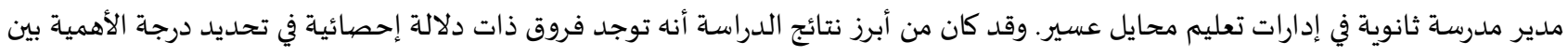

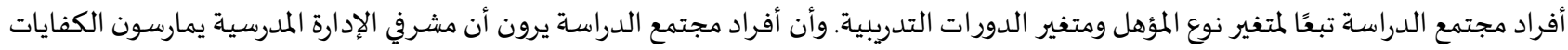

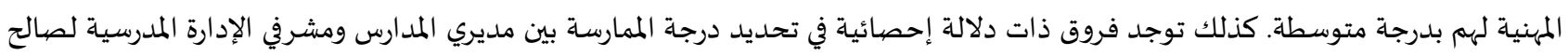
مشرفي الإدارة المدرسية. كما توجد فروق ذات دلالة إحصائية في تحديد درجة الممارسة بين أفراد مجتمع الدراسة تبعًا لمتفير سنوات الخمات الخبرة في العمل

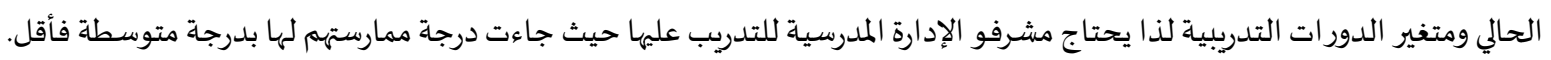

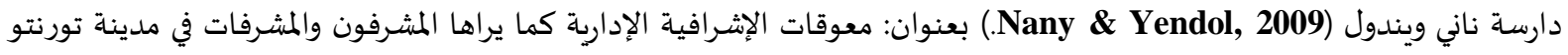
بكندا. وهدفت الدراسة إلى الكشف عن معوقات الإشراف كما يراها المشرفون الإداريون في مدينة تورنتو بكندا في ضوء والدوان متغيرات الجنس والمؤهل

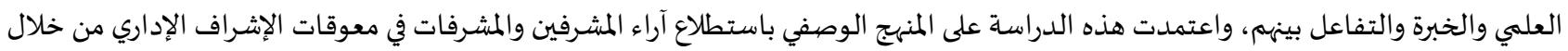

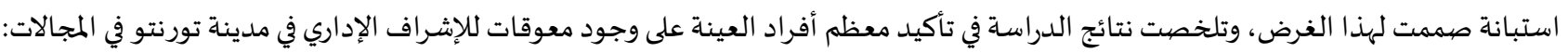

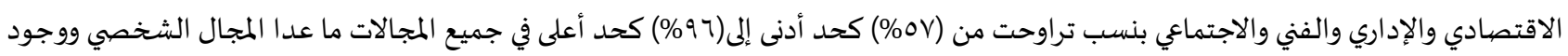
اختلاف في آراء أفراد العينة حول معوقات الإشراف في المجال الاقتصادي لصالح المشرفات. 
أجرى ألجير وتشيزهيك (Alger \& Chizhik, 2006.) دراسة بعنوان: واقع الممارسات الإشرافية التي يمارسها المشرفون الإداريون في

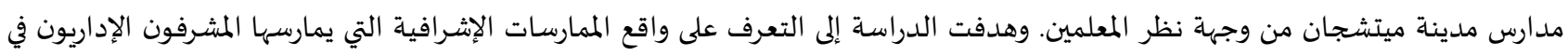

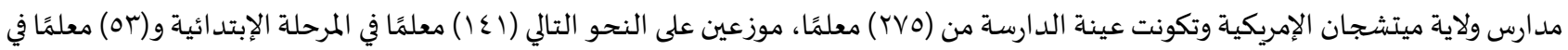

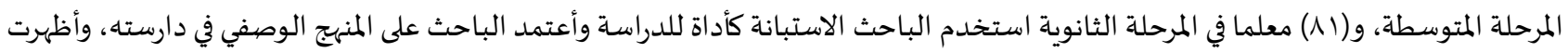
الدراسة مجموعاة من النتائج أهمها: عدم وجود فروق ذات دلالة إحصائية في الممارسات الإشرافية التي يمارسها المشرفون الإداريون في ولاية

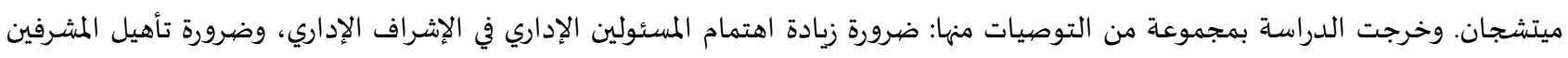

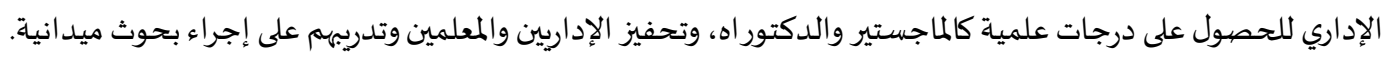

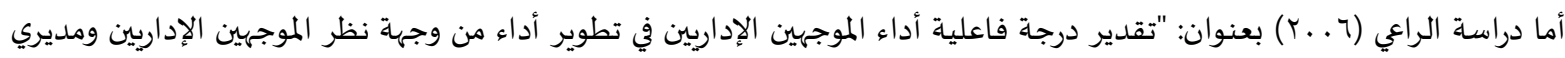

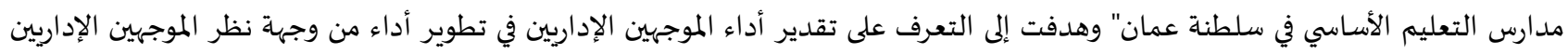

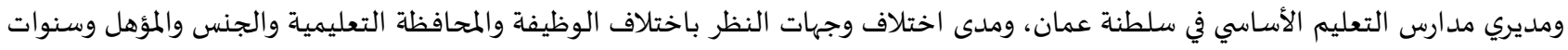

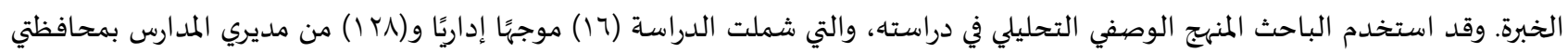

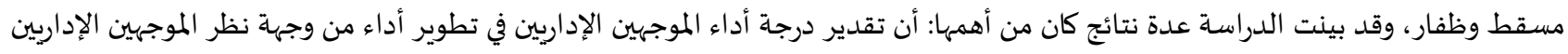

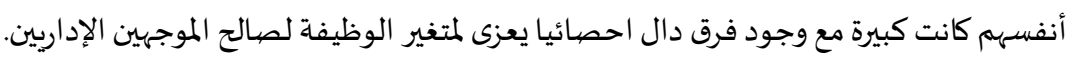

$$
\text { ويتضح لنا من خلال استعراض الدراسات السابقة ما يأتي: }
$$

استخدمت غالبية الدراسـات السابقة المنهج الوصفي وذلك لمناسبة هذا النوع من الدراسات، كما استخدمت الاستبانة كأداة لجمع البيانات التي

$$
\text { تتعلق بالدراسـة. }
$$

ندرة الدراسات التي تناولت بالتحليل تطوير ممارسات المشرفين الإدارين في ضوء مبادئ الجودة الشاملة.

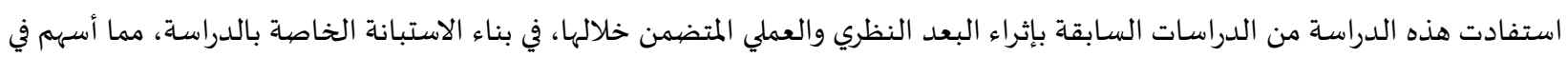

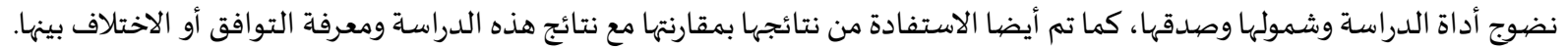
اختلفت هذه الدراسة عن الدراسات السابقة وتميزت عنها في كونها تعد أول دراسة تناولت تطوير ممارسات المشرفين الإداربين في وزارة التربية والتعليم بسلطنة عمان في ضوء مبادئ الجودة الشامل.

مشكلة البحث:

في ضوء التوجهات الحديثة لتجويد العمل في المؤسسات التعليمية وسعي الأنظمة التربوية للأخذ بمبادئ الجودة الشاملة في تحسين المخرجات التعليمياة، ورغم الجهود التي تبذلها وزارة التربية والتعليم في سلطنة عمان للارتقاء بممارسات المشـفين الإداريين، إلا إن نتائج الدراسات

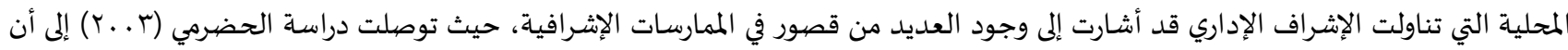

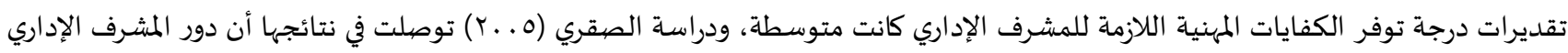

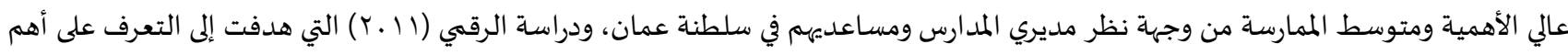

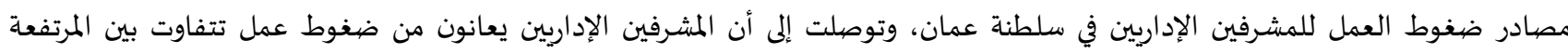

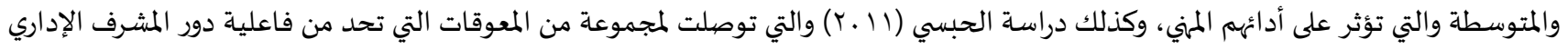

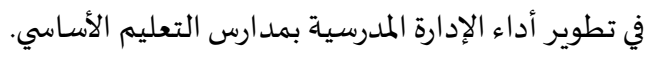
وبما أن الباحث من الحقل التربوي تدرج فياه، بدءاً من معلم ومساعد مدير ثم مدير مدرسة والآن يشغل وظيفة مشرفاً إدارياً، وكونه معايشاً

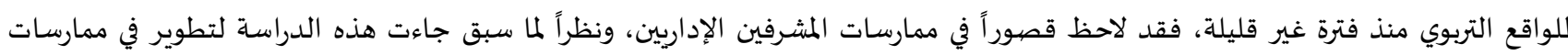
المشرفين الإداريين في ضوء مبادئ الجودة الشاملة، لذا تجيب هذه الدراسة عن السؤال الرئيس التالي: كيف يمكن تطوير الممارسات الإشرافية

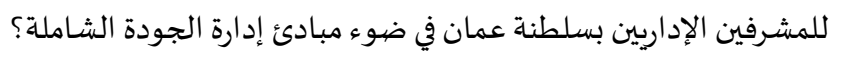
ويتفرع منه الأسئلة الفرعية التالية:

ما متطلبات تطوير الممارسات الإشرافية للمشرفين الإداريين بسلطنة عمان في ضيوء مبادئ الجودة الشاملة من وجهة نظر المشرفين

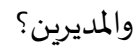
هل توجد فروق ذات دلالة إحصائية في متوسط تقديرات المشرفين الإداريين والمديرين لمستوى الممارسات الإشرافية للمشرفين الإداريين

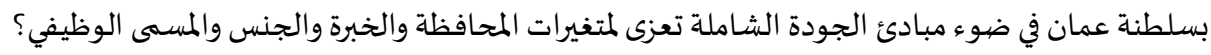

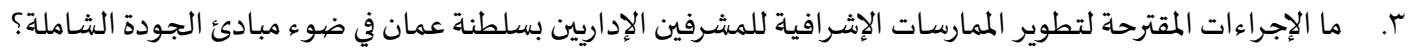




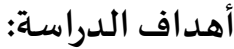

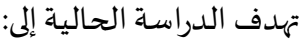

بيان متطلبات تطوير الممارسات الإشرافية للمشرفين الإداريين بسلطنة عمان في ضوء مبادئ الجودة الشاملة من وجهة نظر المشرفين

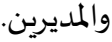
بيان الاختلاف والاتفاق في وجهة نظر كل من المشرفين الإداريين والمديرين لمستوى الممارسات الإشرافية للمشرفين الإدارين بسلطنة عمان في ضوء مبادئ الجودة الشاملة. r. وضع إجراءات مقترحة لتطوير الممارسات الإشرافية للمشرفين الإداريين بسلطنة عمان في ضوء مبادئ الجودة الشاملة.

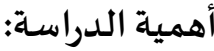

يتوقع أن تسهم الدراسة في: ا. توظيف مبادئ الجودة الشاملة في الممارسات الإشراف الإداري. قد تفيد هذه الدراسة الباحثين والدارسين لموضيوعي الإشراف الإداري والجودة الشـاملة، وتوجياء الجهود لمزيد من الدراسـات اللاحقة التي تتناول عملية الإشراف الإداري وتطوير أساليبها وممارساتها في ضوء الجودة الشاملة.

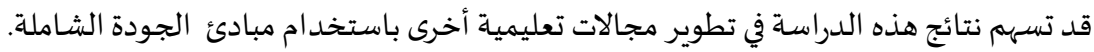

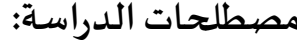

الإشراف الإداري: يقصد باه الجهود التربوية والفنية ولإدارية المنظمة التي يبذلها المشرفون الإداريون بالمناطق التعليمية؛ لتقويم الأساليب

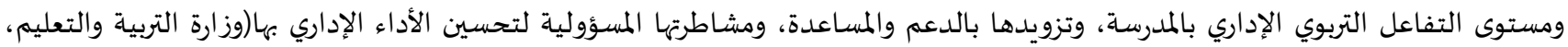

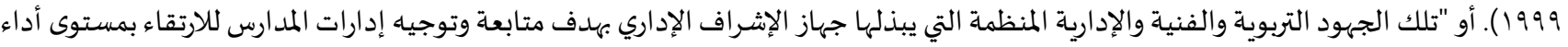
المدرسة كوحدة إدارية وفنية لتطوير العملية التعليمية، ومعالجة جوانب الضعف، وتعزيز الايجابيات إلى أفضل جوانب الأداء الماديه المدرسي" (وزارة التربية

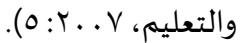
المشرف الإداري: هو المسؤول عن تطوير الأداء الإداري بالمدرسة من خلال الدعم والمساعدة والمشاركة في المسؤولية مع إدارة المدرسة (وزارة

$$
\text { التربية والتعليم، 0. ب. (†). }
$$

مفهوم الممارسات الإشرافية للمشرفين الإداريين إجرائيا: بأنه مجموعة من الأعمال الإجرائية التي يقوم بها المشرف الإداري من أجل تطوير

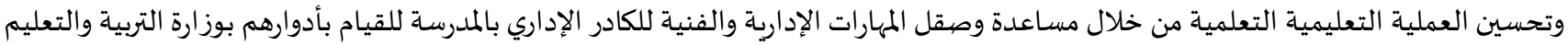
في سلطنة عمان.

مفهوم إدارة الجودة الشـاملة في مجال التعليم: "هو تطبيق مجموعاة من المواصفات التعليمية والتربوية اللازمة لرفع مستوى المنتج التعليمي

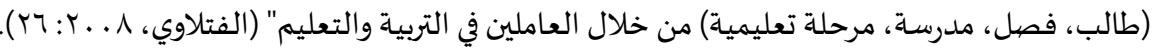

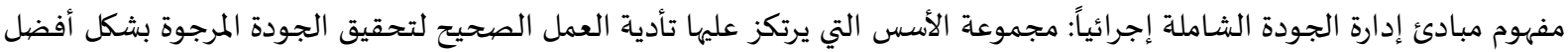
وفعالية أكبر في أقصر وقت ممكن، مع الاعتماد على تقويم المستفيد في معرفة مدى تحسن الأداء من خلال المبادئ التالية (التركيز على المستفيدين

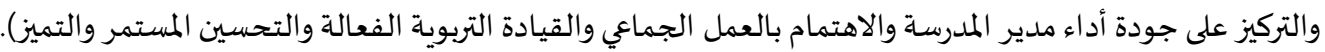

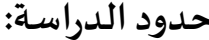

أ. الحدود المكانية: تم تطبيق هذه الدراسة الحالية في المحافظات التعليمية الآتياة: (مسقط، جنوب الباطنة، شمال الباطنة، الداخلية). ب. الحدود البشرية: اقتصرت الدراسة على مديري المدارس والمشرفين الإدارين في سلطنة عمان.

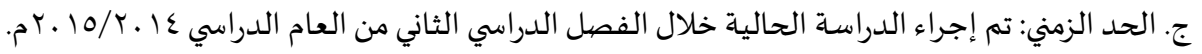
د. الحدود الموضوعياة: نظرًا لاتساع موضوعي الإشراف الإداري، والجودة الشاملة، ستقتصر الدراسة على تطوير الممارسات الإشـرافية للمشرفين

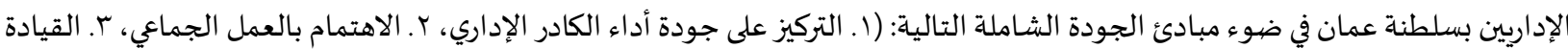
التربوية الفعالة، ع. التحسين المستمر والتميز). 


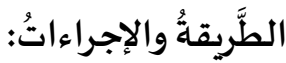

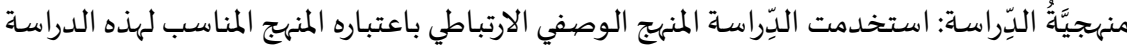
مجتمع الدِّراسة: تكون مجتمع الدراسة من جميع مديري المدارس الحكومية والمشرفين الإداريين في المديريات التعليمية بمحافظات السلطنة وهي:

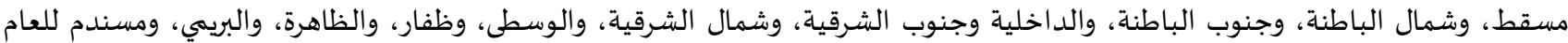

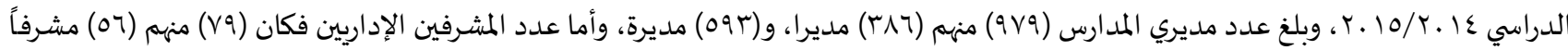

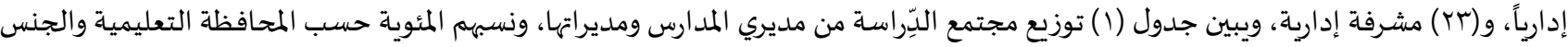

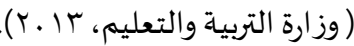

الوظيفة:

جدول (1) : توزيع مجتمع الدِّراسة"* حسب المحافظة التعليمية والمسسمى الوظيفي

\begin{tabular}{|c|c|c|c|c|c|c|c|c|}
\hline \multicolumn{4}{|c|}{ المشرفون الإداريون } & \multicolumn{4}{|c|}{ مديرو المدارس ومديراتها } & \multirow{2}{*}{ المحافظة } \\
\hline النسبة المئوية & المجموع & أنثى & ذكر & النسبة المئوية & المجموع & أنثى & ذكر & \\
\hline$\% \backslash 1, \varepsilon$ & 9 & $\varepsilon$ & 0 & $\% \backslash r, \Lambda$ & 1ro & $\Delta r$ & or & الداخلية \\
\hline$\% \backslash r, V$ & 1. & $\varepsilon$ & 7 & $\% 11,0$ & 114 & $V r$ & $\varepsilon$ & جنوب الباطنة \\
\hline$\%$ \% Y,A & 11 & $r$ & 17 & $\% \backslash \vee, \vee$ & IVTr & $1 . V$ & 77 & شمال الباطنة \\
\hline$\% \vee, 7$ & 7 & r & $\varepsilon$ & $\% \backslash r, q$ & 1ry & $q r$ & $\varepsilon r$ & مسقط \\
\hline$\% 1 ., 1$ & $\Lambda$ & $r$ & 7 & $\% \vee, \vee$ & vo & $\varepsilon_{0}$ & $r$. & شمال الشرقية \\
\hline$\% \vee, 7$ & 7 & $r$ & $r$ & $\% 9, r$ & 9. & 00 & ro & جنوب الشرقية \\
\hline$\% 1, r$ & 1 & . & 1 & $\% 1,1$ & 11 & r & 9 & الوسطى \\
\hline$\% 1 r, q$ & 11 & $r$ & 9 & $\% \backslash r, r$ & $1 r q$ & 71 & 71 & ظفار \\
\hline$\% \wedge, 9$ & V & $r$ & $\varepsilon$ & $\% \vee, \varepsilon$ & Vr & $\varepsilon r$ & r & الظاهرة \\
\hline$\% 1, r$ & 1 & . & 1 & $\% \curlyvee, \wedge$ & TV & 10 & Ir & البريمي \\
\hline$\% \curlyvee, 0$ & $r$ & 1 & 1 & $\% 1, \vee$ & IV & 1. & V & مسندم \\
\hline$\% 1 \ldots$ & 89 & r & 07 & $\% 1 \ldots$ & $9 \vee 9$ & 095 & r人t & المجموع \\
\hline
\end{tabular}

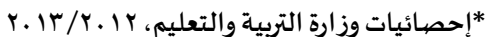

عينة الدِّراسة:

تم اختيار عينة من جميع مديري المدارس الحكومية والمشرفين الإداريين في المديريات التعليمية بالمحافظات الآتية: مسقط، وشمال الباطنة،

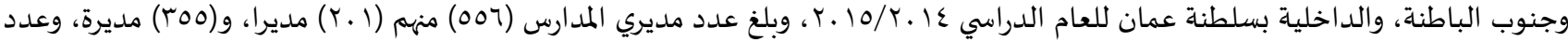

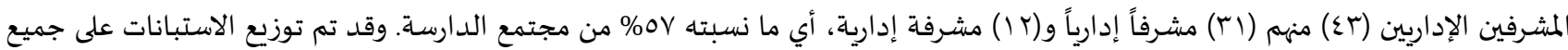

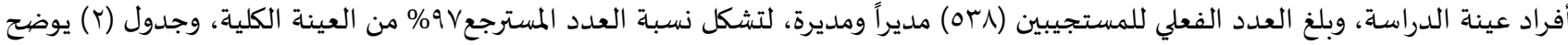

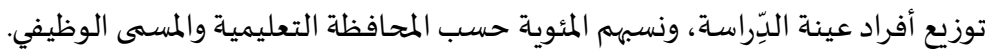

جدول (Y): توزيع أفراد عينة الدِّراسة حسب المحافظة التعليمية والمسسى الوظيفي.

\begin{tabular}{|c|c|c|c|c|c|c|c|c|}
\hline \multicolumn{4}{|c|}{ المشرفون الإداريون } & \multicolumn{4}{|c|}{ مديرو المدارس ومديراتها } & \multirow{2}{*}{ المحافظة الوظيفة } \\
\hline النسبة المئوية & المجموع & أنثى & ذكر & النسبة المئوية & المجموع & أنثى & ذكر & \\
\hline$\%$ r., & 9 & $\varepsilon$ & 0 & $\% \curlyvee \varepsilon, 1$ & $1 T \varepsilon$ & NT & or & الداخلية \\
\hline$\% r r, r$ & 1. & $\varepsilon$ & 7 & $\% \curlyvee ., r$ & $11 \pi$ & $\mathrm{vr}$ & $\varepsilon$. & جنوب الباطنة \\
\hline$\% \varepsilon 1,9$ & 11 & r & 17 & $\%$ \%, & IVr & $1 . v$ & 77 & شمال الباطنة \\
\hline$\% \mid r, q$ & 7 & r & $\varepsilon$ & $\% \curlyvee \varepsilon, 0$ & $1 \pi 7$ & qr & $\varepsilon r$ & مسقط \\
\hline$\% 1 .$. & $\varepsilon r$ & Ir & $\mu_{1}$ & $1 .$. & 007 & roo & r. 1 & المجمموع \\
\hline
\end{tabular}

أداة الدِّراسـة: - ماسِ

قام الباحث بإعداد استبانة تكونت من (r) بندا للكشف عن الممارسات الإشرافية للمشرفين الإداريين بسلطنة عمان في ضوء مبادئ

الجودة الشاملة موزعة على أربعة مبادئ. وجدول (r) يوضح توزيع بنود الاستبانة على مبادئ الدِّراسة المختلفة. 
جدول(r): توزيع بنود الاستبانة على مبادئ الدِّراسة المختلفة

\begin{tabular}{|c|c|c|c|}
\hline عدد البنود & البنود & المجال & م \\
\hline it & $\mid r-1$ & التركيز على الكادر الإداري & 1 \\
\hline$\wedge$ & $t \cdot-14$ & الاهتمام بالعمل الجماعي & r \\
\hline 9 & $|r q-4|$ & القيادة التربوية الفعالة & $r$ \\
\hline 9 & rN-r. & التحسين المستمر والتميز & $\varepsilon$ \\
\hline
\end{tabular}

صدق الأداة:

للتأكد من صدق الأداة اعتمد الباحث على الصددق الظّاهري لفقرات الاستبانة، فعرضت الاستبانة في صورتها الأولية على مجموعة من المحكمين بلغ عددهم (r (Y) محكمًا من حملت شهادة الدكتوراه في الإدارة التربوية وعلم النفس التربوي والإشراف التربوي لمعرفة مدى ارتباط البنود

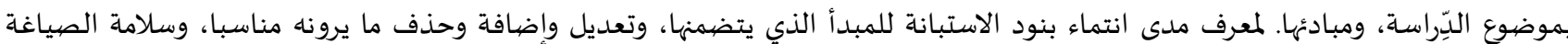
اللغوية لبنود الاستبانة. وفي ضوء آراء المحكمين، وملاحظاتهم، وتوجيهاتهم، قام الباحث بإجراء التعديلات المناسبة، من حذف وإضافة وتعديل. وأصبحت الاستبانة بصورتها الهائية (بر) بندًا.

ثبات الأداة:

للتأكد من ثبات الأداة تم تطبيقها على عينة عشـوائية من مجتمع الدِّراسة نفسه مكونة من (.؟r) مديرًا ومشرفًا إداريًا، ولحسـاب الاتساق

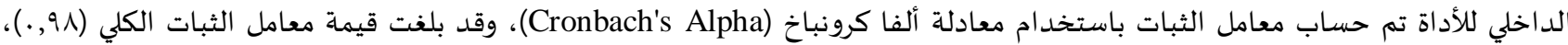

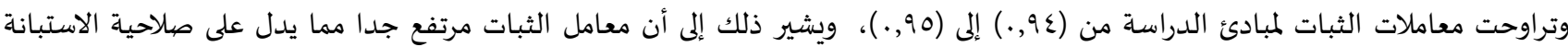
للاستخدام لأغراض الدِّراسـة، وجدول (ع) يوضح معاملات الثبات المحسوبة لكل مبدأ من مبادئ اليّراسة.

جدول(ع): معامل ثبات ألفا كرونباخ على مجالات الأداة وعدد مبادئها والدرجة الكلية

\begin{tabular}{|c|c|c|}
\hline عل عدد البنود & معامل الثبات & المجالات \\
\hline IT & .90 & التركيز على الكلادر الإداري \\
\hline$\wedge$ &., 90 & الاهتمام بالعمل الجماعي \\
\hline 9 &., 90 & القيادة التربوية الفعالة \\
\hline 9 & . $9 \varepsilon$ & التحسين المستمر والتميز \\
\hline$r_{\Lambda}$ &., 91 & الدرجة الكلية \\
\hline
\end{tabular}

المعالجات الإحصيائية:

بعد نقل الباحث الاستبانات التي تم جمعها في قاعدة البيانات، تمت معالجتها إحصائياً باستخدام برنامج الرزمة الإحصائية (SPSS)

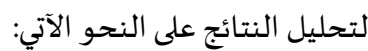
ا. . معادلة ألفا كرونباخ (Cronbach's Alpha) لتحديد معامل الثبات.

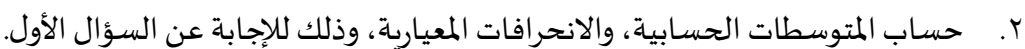

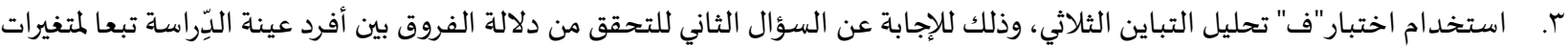

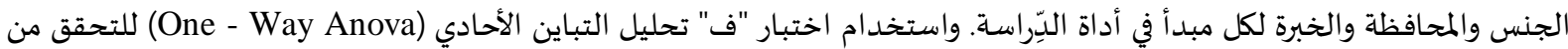

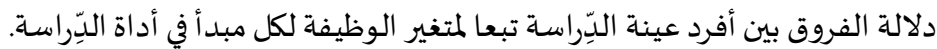

عرض النتائج وتفسيرها: أولاً مناقشة النتائج المتعلقة بالإجابة عن السؤال الأول ونصاه: "ما متطلبات تطوير الممارسات الإشرافية للمشرفين الإدارين بسلطنة عمان في ضوء

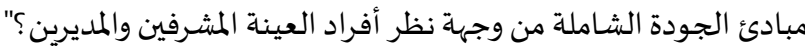

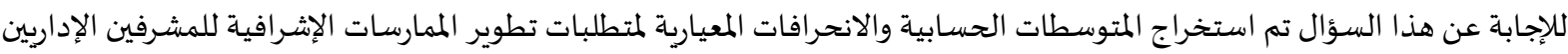

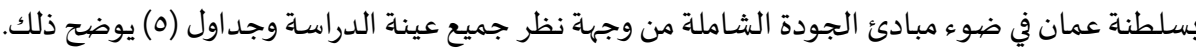
جدول (0): المتوسطات الحسابية والانحر افات المعيارية لاستجابات جميع أفراد عينة الدراسة مرتبة تنازلياً حسب المتوسطات المبات الحسابية

\begin{tabular}{|c|c|c|c|c|c|}
\hline المستوى & الانحراف المعياري & المتوسط الحسابي & المبدأ & 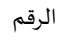 & 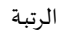 \\
\hline متوسط مت & . 7or & $r, I r$ & الاهتمام بالعمل الجماعي & r & 1 \\
\hline متوسط & . & $r, 11$ & القيادة التربوية الفعالة & r & r \\
\hline متوسط & . & $r, .1$ & التحسين المستمر والتميز & $\varepsilon$ & $r$ \\
\hline متوسط مت &., 707 & $r, . \varepsilon$ & التركيز على الكادر الإداري & 1 & $\varepsilon$ \\
\hline متوسط مت & . $T$ T & $r, . \Lambda$ & الدرجة الكلية & & \\
\hline
\end{tabular}




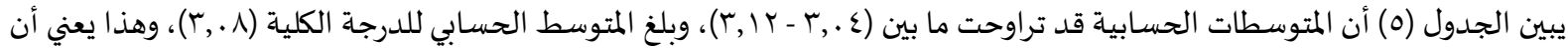

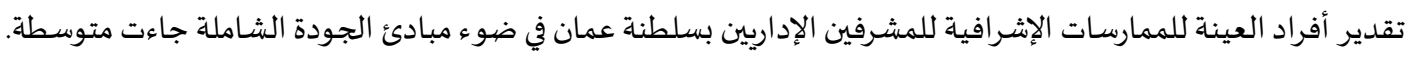

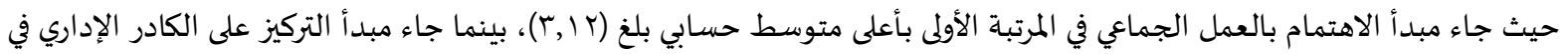

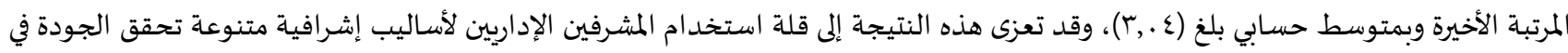

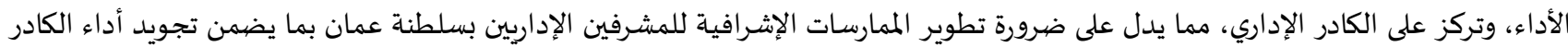

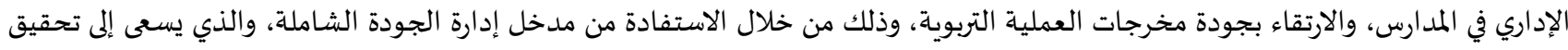

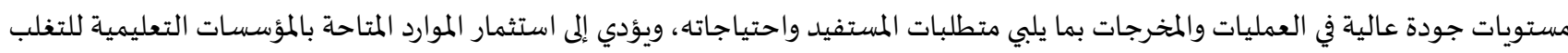

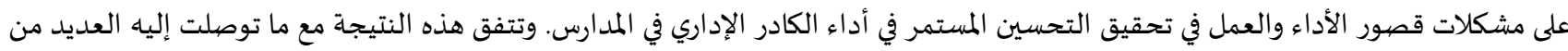

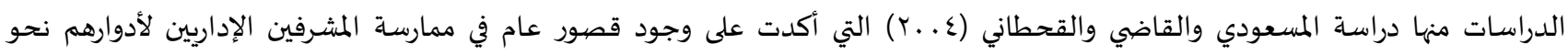

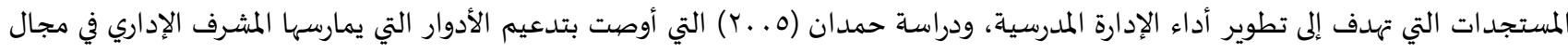

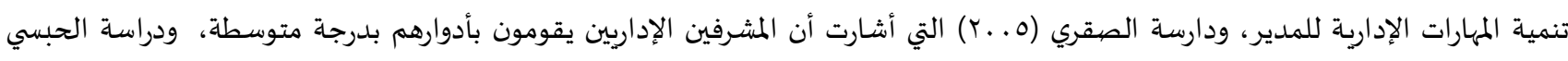

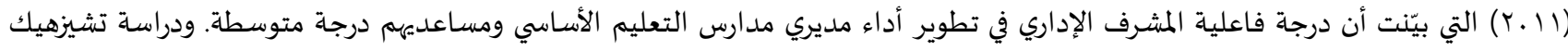

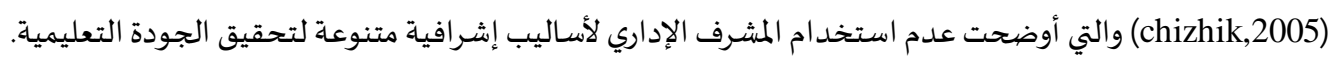

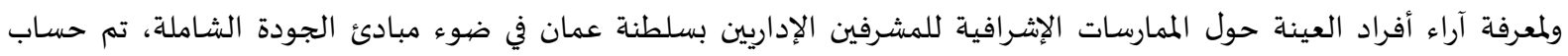

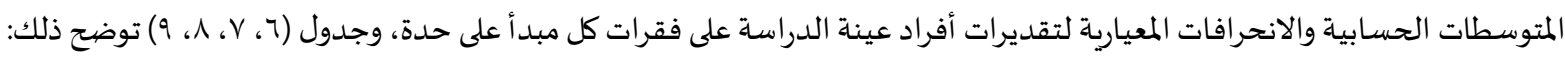

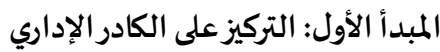

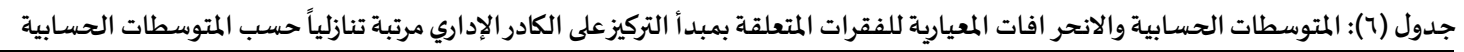

\begin{tabular}{|c|c|c|c|c|c|}
\hline 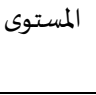 & 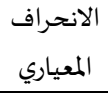 & المتوسط المسبي & 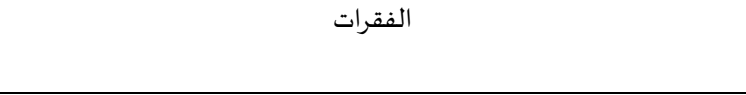 & 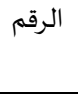 & الرتبة \\
\hline متوسط &., $9 \vee T$ & r, rq & يوظف السجلات الإشرافية التراكمية في البوابة التعليمية لمتابعة أداء الكادر & 11 & 1 \\
\hline 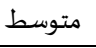 & $\cdot, 10 \mathrm{~V}$ & r, ru & يساهم في بناء الخطة التطويرية السنوية للمدرسـة. & r & r \\
\hline 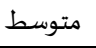 & $\cdot, \wedge 1 \vee$ & r,IV & يَعْتَبر الكادر الإداري الأساس في تصميم الخدمة الإشرافية. & 1 & r \\
\hline 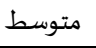 & $\cdot, \mathrm{VV} \varepsilon$ & $r, 17$ & يساهم في امتلاك الكادر الإداري المهارات الأساسية في الإدارة المدرسية. & $\varepsilon$ & $\varepsilon$ \\
\hline متوسط & .,VYY & $r, 17$ & يقدم التغذية الراجعة الفورية لعلاج المواقف السلبية. & ir & 0 \\
\hline 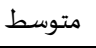 & $\cdot, V \varepsilon r$ & r,ir & يساعد على تنمية أفراد الكادر الإداري الجدد مهنياً بمختلف الوسائل المتاحة. & v & 7 \\
\hline 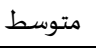 & $\cdot, \wedge \cdot \vee$ & $r, . \Lambda$ & يوظف أسلوب القراءات الموجهاة مع الكادر الإداري لتطوير العمل المدرسي. & $\Lambda$ & v \\
\hline 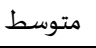 & $\cdot, V \leqslant V$ & $r, .7$ & يوظف أدوات متعددة للكشف عن حاجات الكادر الإداري. & 0 & $\wedge$ \\
\hline متوسط &.,$\vee \vee q$ & r,qr & يضع مؤشرات أداء واضحة لكل معيار يقيس أداء الكادر الإداري. & 9 & 9 \\
\hline متوسط & $\cdot, \wedge \wedge 7$ & r,A. & يسعى إلى ربط احتياجات الكادر الإداري بأهداف جودة الأداء المدرسي. & 7 & 1. \\
\hline 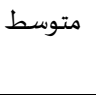 &., 9.7 & r,vq & يقوم بعمليات المراجعة المستمرة لأداء الكادر الإداري في ضوء معايير جودة & 1. & 11 \\
\hline 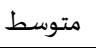 &., $91 \mathrm{~V}$ & $r, 70$ & يعتبر تحقيق حاجات الكادر الإداري مقياساً مهماً للجودة. & r & ir \\
\hline متوسط &., 707 & $r, . \varepsilon$ & التركيز على الكادر الإداري ككل & & \\
\hline
\end{tabular}

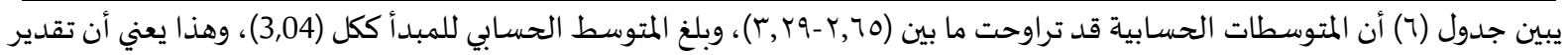

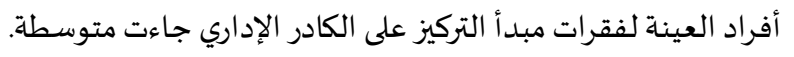
وقد جاءت الفقرة (1) وتنص على "يوظف السجلات الإشرافية التراكمية في البوابة التعليمية لمتابعة أداء الكادر الإداري" في المرتبة الأولى وبمتوسط حسابي بلغ (وץ,ץ)، وقد يعزى ذلك إلى التوجه الذي انتهجته وزارة التربية والتعليم بسلطنة عمان والقائم علئم على مواكبة المستجدات

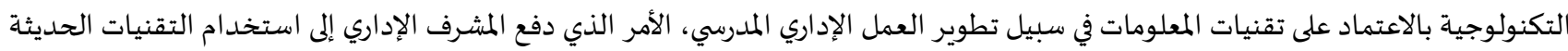

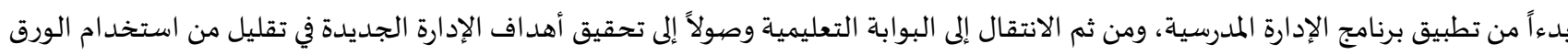

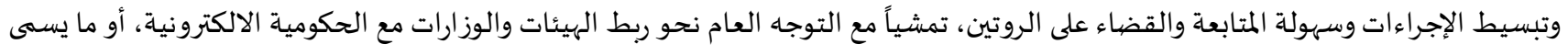

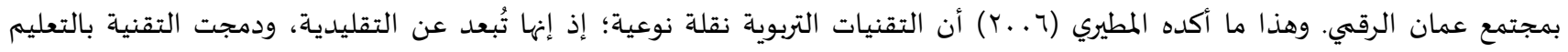

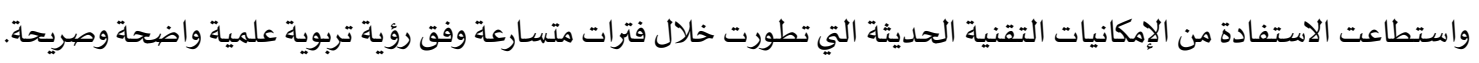


جاءت الفقرة (r) ونصهيا "يعتبر تحقيق حاجات الكادر الإداري مقياساً مهماً للجودة" بالمرتبة الأخيرة وبمتوسط حسابي بلغ (r,70) وقد يعزى

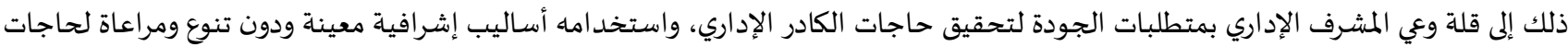
الكادر الإداري المهنية المختلفة، وينبغي على المشرف الإداري أن يحرص على تلمس الحاجات التربوية التي قد يحتاج إلها مديرو المدارس، واقتراح

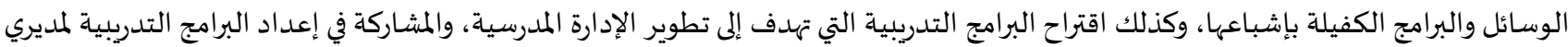
المدارس، وتنفيذها بالتنسيق والتعاون مع جهات الاختصاص الأخرى، كما يقوم المشرف الإداري بالتعرف على أثر البرامج التدريبية التي التحق بها مدير إلتردير

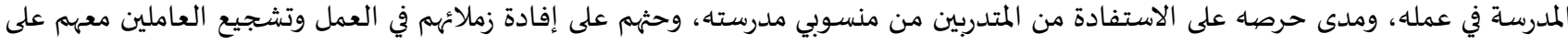

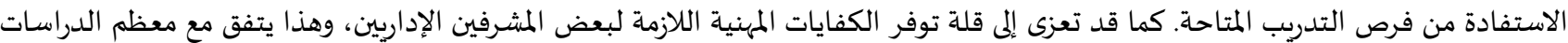

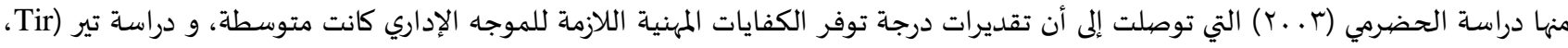

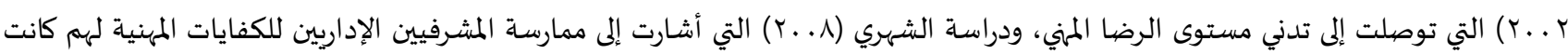
متوسطة، ودراسة الغافري (ع ا ـب) والتي توصلت إلى أن المشرفين الإداريين يمارسون دورهم في التنمية المهنية بدرجة متوسطة. المبدأ الثاني: الاهتمام بالعمل الجماعي

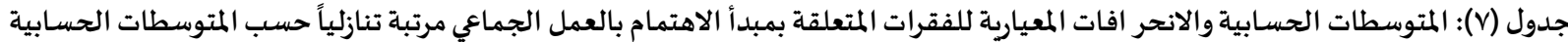

\begin{tabular}{|c|c|c|c|c|c|}
\hline 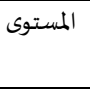 & المعياري & المتوسطب & 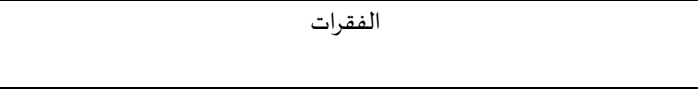 & 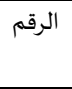 & الرتبة \\
\hline 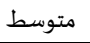 & $\cdot, \mathrm{V} 7 \mathrm{l}$ & $r, 10$ & يوظف أساليب التنمية المهنية الجماعية للارتقاء بأداء الكادر الإداري. & 17 & 1 \\
\hline 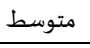 &., Vo. & $r, 1 \varepsilon$ & يعمل على تدعيم مهارات الاتصال بين الأفراد والجماعات المدرسية أفقياً ورأسياً. & 19 & $r$ \\
\hline متوسط & $\cdot$, VKY & $r, i r$ & يوظف فرق عمل لتحليل وتطوير العمل المدرسي. & 10 & $r$ \\
\hline متوسط & $\cdot, \mathrm{V} \varepsilon \mathrm{T}$ & $r, i r$ & يمارس أساليب إشرافية جماعية من أجل تبادل الخبرات بين إدارات المدارس. & IV & $r$ \\
\hline متوسط & $\cdot, \mathrm{VAl}$ & $r, 1$. & يشرف على تشكيل اللجان والمجالس المدرسية المتنوعة وتفعيلها. & Ir & 0 \\
\hline متوسط &., $\mathrm{\wedge} \wedge \mathrm{O}$ & $r, 1$. & يشجع الكادر الإداري على ممارسة أسلوب إشراف الأقران. & 11 & $\circ$ \\
\hline 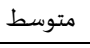 & ., Vov & $r, .9$ & يشجع تكوين الجماعات الطلابية للمشاركة في الأنشطة المدرسية وتفعيلها. & r. & $\mathrm{v}$ \\
\hline متوسط & .,VYO & $r, .1$ & يتابع تفويض الصلاحيات اللازمة للجان المدرسية. & $1 \varepsilon$ & $\wedge$ \\
\hline متوسط & . 7or & r,IT & الاهتمام بالعمل الجماعي ككل & & \\
\hline
\end{tabular}

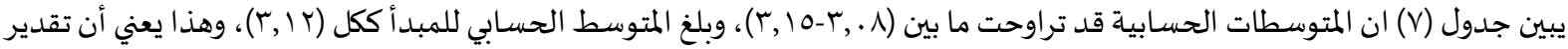

أفراد العينة لفقرات مبدأ الاهتمام بالعمل الجماعي جاءت متوسطة.

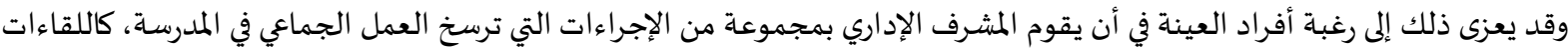
والنشرات التربوية والدورات التدريبية للعاملين، ولا يقتصر العمل الجماعي على الإداريين فقط، وإنما يتعداه ليشمل المعلمين والطلاب وكذلك المجتمع

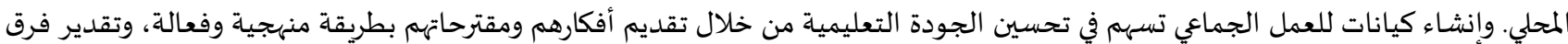

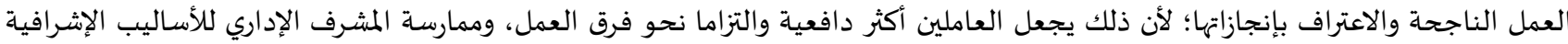

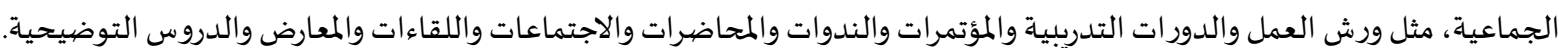
وحازت الفقرة (7 (1) وتنص على "يوظف أساليب التنمية المهنية الجماعية للارتقاء بأداء الكادر الإداري" في المرتبة الأولى وبمتوسط حسابي

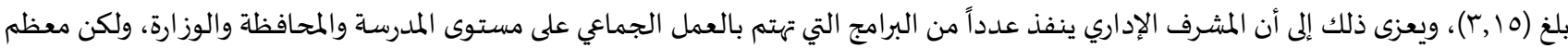

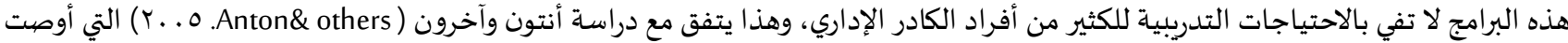

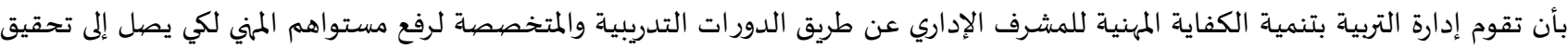

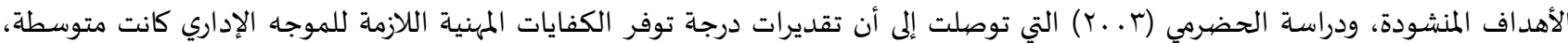

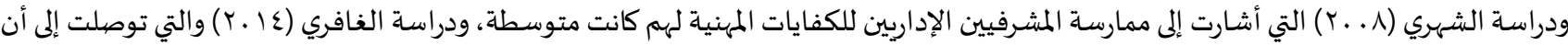

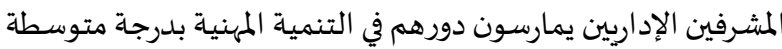
بينما حازت الفقرة (ع ا ) ونصها "يتابع تفويض الصلاحيات اللازمة للجان المدرسية" بالمرتبة الأخيرة وبمتوسط حسابي بلغ (م .,r)، وقد يعزى

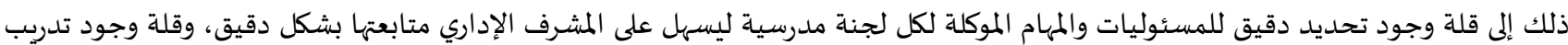
جماعي على آليات العمل بهذه اللجان المدرسية، وربما قلة الوقت الخاص بالمشرف لمتابعة اللجان وضعف تواصله الداخلي في المدرسة مع جميع اللجان المدرسية، وهذا ما يؤكده زاهر (0 . . r) أن العمل الجماعي يتطلب تدريباً على آلياته، و تدعيم الاتصال بين الأفراد، وتبادل للخبرات. 
المبدأ الثالث: القيادة التربوية الفعالة

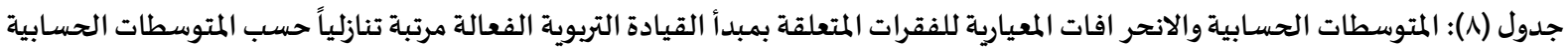

\begin{tabular}{|c|c|c|c|c|c|}
\hline 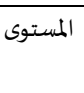 & 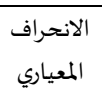 & الحتوسط المسبي & 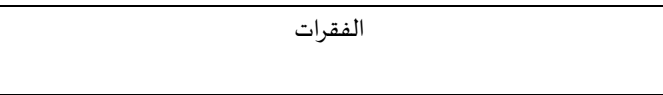 & 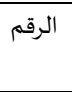 & 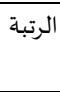 \\
\hline متوسط &.,$\vee \backslash \varepsilon$ & $r, 19$ & يشجع الكادر الإداري على تفويض الصلاحيات. & TV & 1 \\
\hline متوسط &.,$V \varepsilon \wedge$ & $r, 1 \Lambda$ & يتقبل الآراء البناءة التي تسهم في تطوير أدائه. & rt & $r$ \\
\hline متوسط &., $\mathrm{VY \Lambda}$ & $r, I V$ & يشجح على إيجاد بيئة تعليمية تفي باحتياجات جميع المستفيدين بالمدرسة أو & rی & $r$ \\
\hline متوسط & .,VV乏 & $r, 17$ & يبني علاقات ودية مع الكادر الإداري للارتقاء بالعمل المدرسي. & To & $\varepsilon$ \\
\hline متوسط &., $\mathrm{VrV}$ & $r, 17$ & يراعي الفروق الفردية في أداء الكادر الإداري. & rq & $\varepsilon$ \\
\hline متوسط &., $\mathrm{V99}$ & $r, \cdot V$ & يشارك الكادر الإداري في اتخاذ القرارات. & $T \varepsilon$ & 7 \\
\hline متوسط & ., $\mathrm{V} 10$ & $r, \cdot V$ & يساهم في عمليات التغيير في المدرسة من أجل رفع مستوى كفاءة أدائها. & r7 & 7 \\
\hline متوسط & . Ar & $r, . \varepsilon$ & يساهم في التعامل مع التحديات التي تواجه العمل المدرسي. & $r$ & $\wedge$ \\
\hline متوسط &.,$\lambda \cdot 1$ & r,91 & يقوم بتحديد استراتيجيات العمل التي توجه أداء الكادر الإداري في المدرسة. & ri & 9 \\
\hline 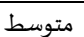 & . & $r, 11$ & القيادة التربوبة الفعالة ككل & & \\
\hline
\end{tabular}

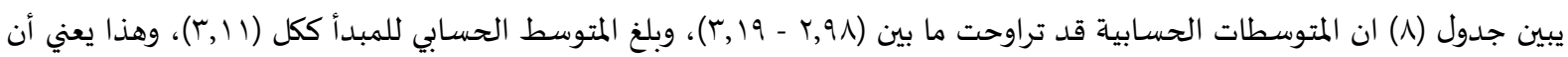

تقدير أفراد العينة لفقرات مبدأ القيادة التربوية الفعالة جاءت متوسطة.

وقد جاءت فقرات هذا المحور جميعها بدرجة متوسطة والتي تشير إلى ما يتعلق بالتفويض ودراسة الاحتياجات والمشاركة في اتخاذ القرار وتحديد الاستراتيجيات وهذه جميعها تحتاج إلى وعي بمتطلبات الجودة، وهذا يتطلب اشراك جميع العاملين في المدرسة وإقناعهم بأهمية أي تغيير يتم بـأي

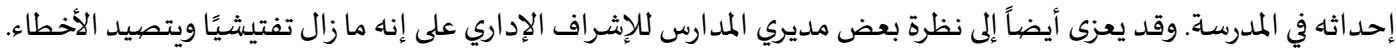

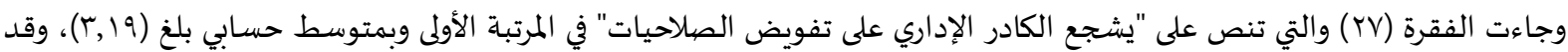

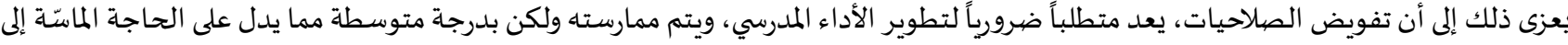

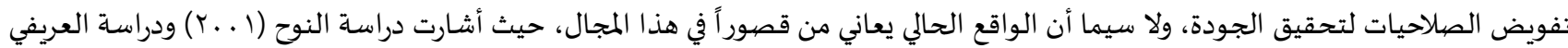
(Y ( . . على ضرورة فاعلية دور المشرف الإداري في تطوير أداء الكادر الإداري.

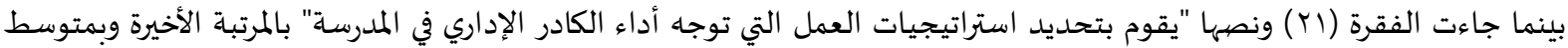
حسابي بلغ (1) (Y,). وقد يعزى ذلك إلى بعض النقص في مهارات التخطيط والرؤية الإشرافية، ويعتمد المشرف الإداري على استراتيجيات تقليدية تنفذ

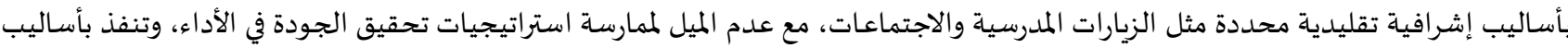

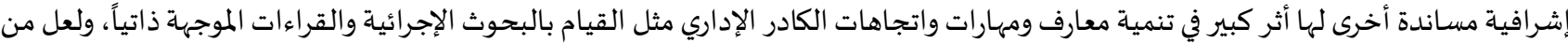
أسباب عزوف المشرف الإداري عن هذه الأساليب العدد الكبير من الكادر الإداري الذين يتولى الإشراف عليهم؛ مما يصعب تحديد الحاجات المعرفية

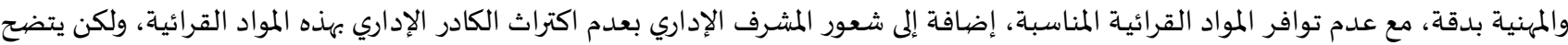

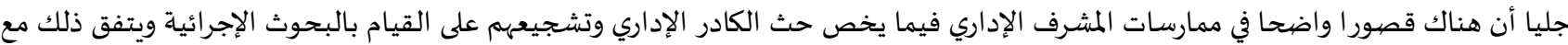

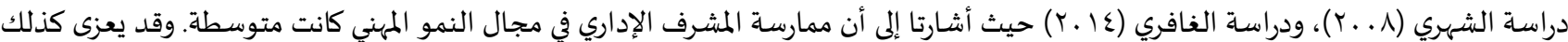
إلى قلة إدراك المشرفين الإداريين لأهمية التخطيط في المدرسة، وهذا يتفق مع دراسة سنيدير (Snyder,2005) والتي توصلت إلى ضرورة التخطيط

لتحقيق جودة التعليم الذي يساير احتياجات الخطط التنموية. المبدأ الر ابع: التحسين المستمروالتميز

جدول (9): المتوسطات الحسابية والانحر افات المعيارية للفقرات المتعلقة بمبدأ التحسين المستمروالتميز مرتبة تنازلياً حسب المتوسطات الحسابية

\begin{tabular}{|c|c|c|c|c|c|}
\hline 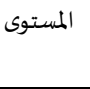 & المعياري & المسابي & 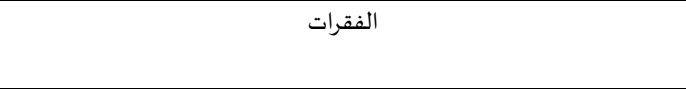 & 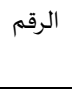 & 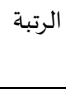 \\
\hline متوسط & ., Vor & $r, r \varepsilon$ & يقوم بعمليات الرقابة المستمرة للتأكد من الالتزام باللوائح والأنظمة المحددة. & r. & 1 \\
\hline متوسط & $\cdot, \mathrm{V} \vee \wedge$ & $r, r)$ & يشجع الإدارة المدرسية على توظيف التقانة في العمل الإداري. & ro & r \\
\hline 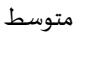 & ., $\vee \vee q$ & $r, 19$ & يعمل على تنمية روح المسؤولية والتنافس الإيجابي بين الكوادر الإدارية للارتقاء & Tr & $r$ \\
\hline متوسط &., $\mathrm{A.9}$ & $r, 10$ & يوظف التغذية الراجعة لنظام تطوير الأداء المدرسي. & ru & $\varepsilon$ \\
\hline 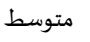 & $\cdot, \mathrm{Vr \Lambda}$ & $r, 11$ & يشجع أولياء الأمور في دعم النشاطات المدرسية. & $r \varepsilon$ & $\circ$ \\
\hline
\end{tabular}




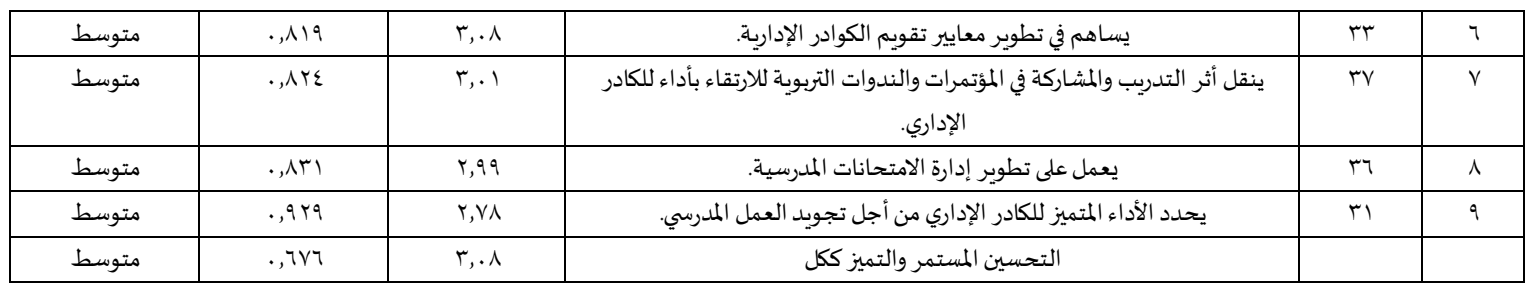

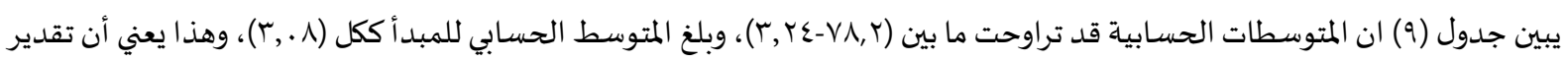

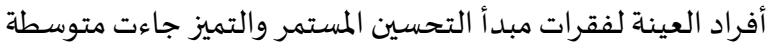

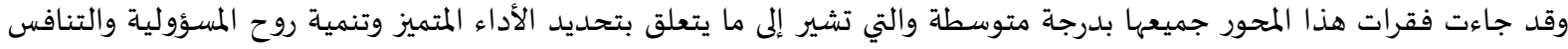

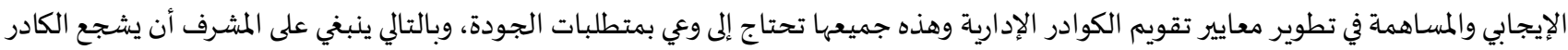

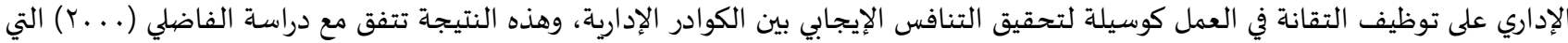

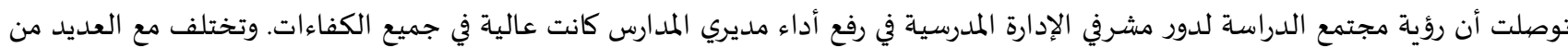

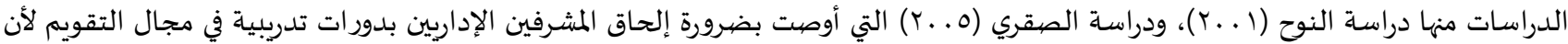
درجة ممارستهم لهذا الدور كانت متوسطة.

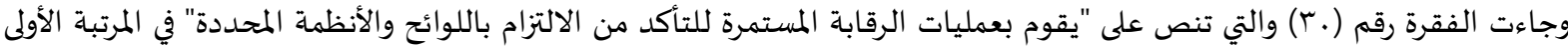

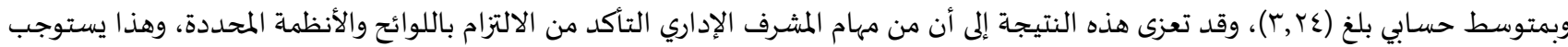

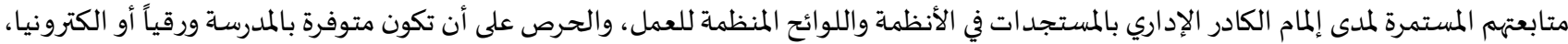

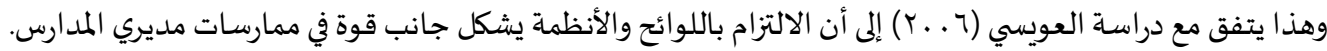

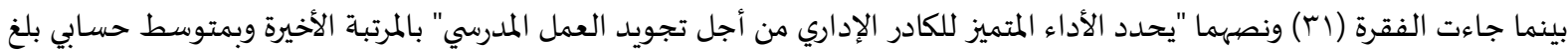

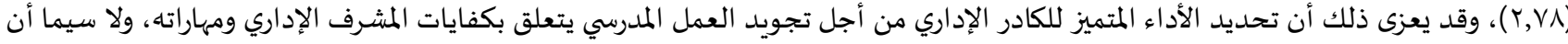

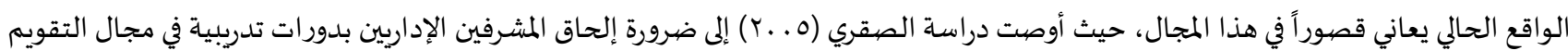
لأن درجة ممارستهم لهذ الدور كانت متوسطة.

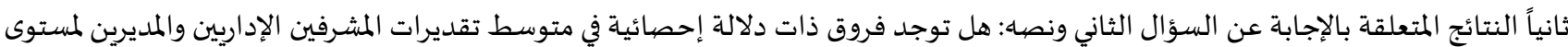

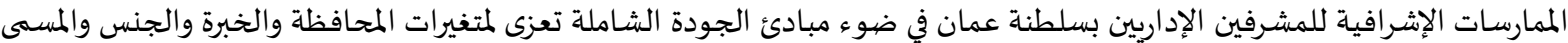
للإجابة عن هذا السؤال تم استخراج المتوسطات الحسابية والانحرافات المعيارية لمتوسط تقديرات المشرفين والمديرين لمستوى الممارسات

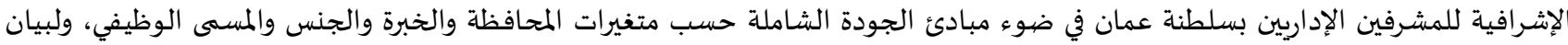

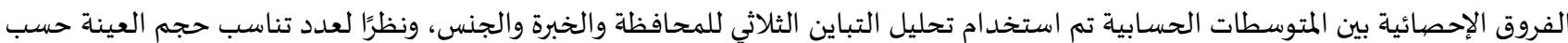

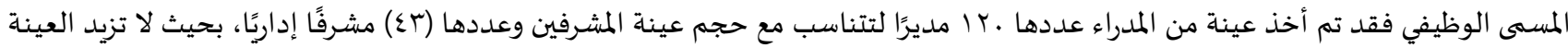

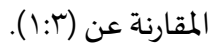

أولاً: متغيرات المحافظة والخبرة والجنس

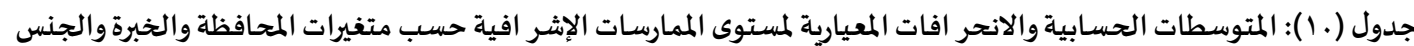

\begin{tabular}{|c|c|c|c|c|}
\hline العدد & الانحراف المعياري & المتوسط الحسابي & & \\
\hline 1ro & .011 & $r, 9 \varepsilon$ & الداخلية & المحافظة \\
\hline ITr &., 719 & $r, r$, & جنوب الباطنة & \\
\hline 119 & ـ & $r, . \varepsilon$ & شمال الباطنة & \\
\hline $1 T \varepsilon$ &., 079 & $r, . r$ & مسقط & \\
\hline TrT & ., VVV & $r, r \varepsilon$ & ذكر & الجنس \\
\hline rol &., $0 Y 1$ & $r, 99$ & أنثى & \\
\hline $1 \% \mathrm{r}$ & \& & $r, I V$ & $0-1$ & الخبرة \\
\hline$r \cdot \Lambda$ & . or & $r, 9 \varepsilon$ & $1 .-7$ & \\
\hline rmy & ., $79 \varepsilon$ & $r, 17$ & . أفأكثر. & \\
\hline
\end{tabular}


يبين الجدول (. ا ) تبايناً ظاهرياً في المتوسطات الحسابية والانحرافات المعيارية لمستوى الممارسات الإشرافية للمشرفين الإداريين بسلطنة عمان في ضوء مبادئ الجودة الشاملة بسبب اختلاف فئات متغيرات المحافظة والخبرة والجنس ولبيان دلالة الفروق الإحصائية بين المتوسطات

الحسابية تم استخدام تحليل التباين الثلاثي جدول (11).

جدول (11): تحليل التباين الثلاثي لمعرفة الفروق ذات الدلالة الاحصبائية في ضوء متغيرات المحافظة والخبرة والجنس

\begin{tabular}{|c|c|c|c|c|c|}
\hline الدلالة الإحصائية & قيمة "ف" & متوسط المربعات & درجات الحرية & مجموع المربعات & مصدر التباين \\
\hline.,$\ldots$ & $1 ., \Lambda \leqslant \wedge$ & $\varepsilon, . T \varepsilon$ & $r$ & $|r, \cdot V|$ & المحافظة \\
\hline.,$\ldots$ & $19,9 \mathrm{VT}$ & $\gamma, \varepsilon \cdot \Lambda$ & 1 & $\gamma, \varepsilon \cdot \lambda$ & الجنس \\
\hline \multirow[t]{3}{*}{.,$\ldots 1$} & $7,7 \times 1$ & $r, \varepsilon V \varepsilon$ & r & $V, \varepsilon q \varepsilon$ & الخبرة \\
\hline & & I & OVE & Y Tr,A99 & الخطأ \\
\hline & & & $0 \Lambda$. & $r r q, r \circ 4$ & الكلي \\
\hline
\end{tabular}

يتبين من جدول (l (1) الآتي:

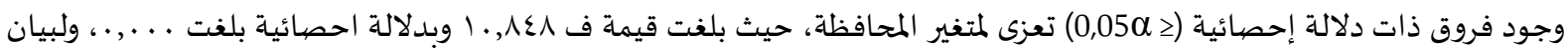
الفروق الزوجية الدالة إحصائيا بين المتوسطات الحسابية تم استخدام المقارنات البعدية بطريقة LSD كما هو مبين في جدول (10).

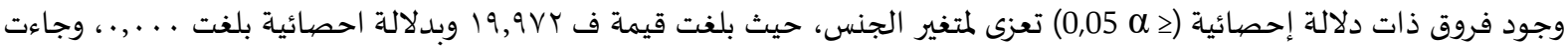
الفروق لصالح الذكور، وقد يعزى ذلك إلى الأوضاع الاجتماعية الخاصة بالإناث من حيث الدور الاجتماعي بعد الدوام المدرسي، مما يؤثر في

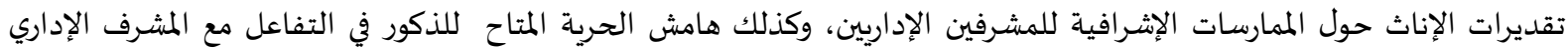
ومناقشاة ممارساته في ضوء الجودة الشاملة هو أكبر من الهامش المتاح للإناث، ويعود ذلك لطبيعة المجتمع العماني المحافظ. وتختلف هذه

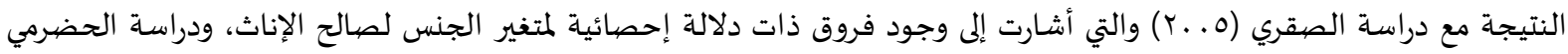

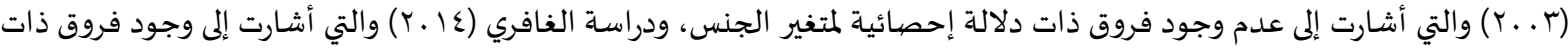
دلالة إحصائية لمتغير الجنس لصالح الإناث.

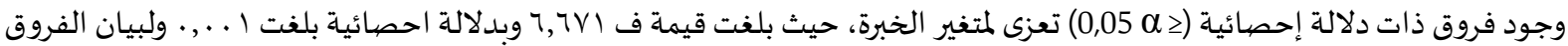

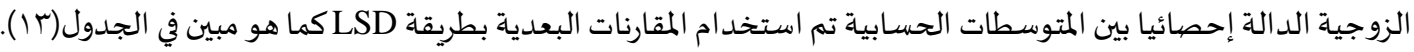
علماً بأن جميع التفاعلات بين المتغيرات المستقلة (المحافظة، والجنس، والخبرة)غير دالة احصائياً عند مستوى .(2) 0,05)

جدول (Y I ) : المقارنات البعدية بطريقة LSD المتغير المحافظة

\begin{tabular}{|c|c|c|c|c|c|}
\hline محافظة مسقط & محافظة شمال الباطنة & محافظة جنوب الباطنة & محافظة الداخلية & المتوسط الحسابي & \\
\hline & & & & $r, q \varepsilon$ & محافظة الداخلية \\
\hline & & & *., $\varepsilon Y-$ & דוז, & محافظة جنوب الباطنة \\
\hline & & *., tr &., $1 .-$ & $r, . \varepsilon$ & محافظة شمال الباطنة \\
\hline &., .1 & * שTr, &., $.9-$ & $r, . r$ & محافظة مسقط \\
\hline
\end{tabular}

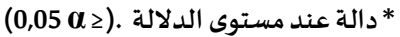

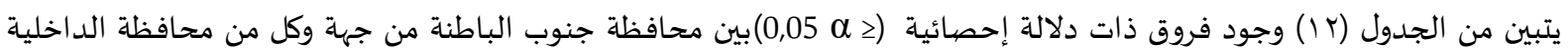

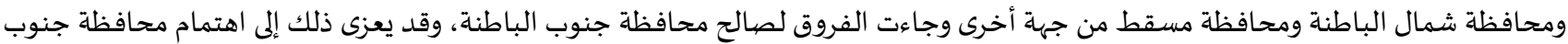

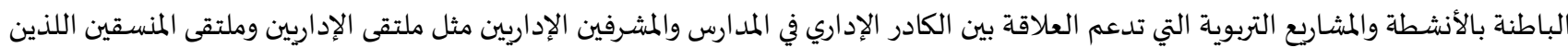
ينفذان كل عام دراسي على مستوى مدارس كل ولاية من ولايات المحافظة، والتي تسهم في إيجاد بيئة مدرسية جاذبة تسهم في الارتقاء بعمليتي التعليم والتعلم، من خلال تنمية وصقل مهارات الكادر الإداري بالمدرسية، والارتقاء بمستواهم المهني، وتشجيعهم لإبراز مواهبهم الفردية والجماعية، ومتابعتهم

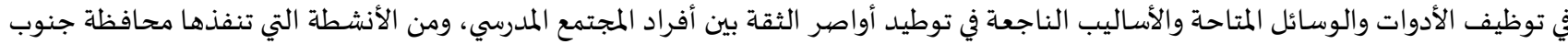
الباطنة الملتقيات الإد ارية لمختلف أفراد الكادر الإداري على مستوى ولايات المحافظة، والدورات التدرببية لمختلف أفراد الكادر الإداري. 
جدول (r ا ): المقارنات البعدية بطريقة LSD لمتغير الخبرة

\begin{tabular}{|c|c|c|c|c|c|}
\hline . أفأكثر & $1 .-7$ & $0-1$ & المتوسط الحسابي & & \\
\hline & & & $r, I V$ & $0-1$ & \multirow[t]{3}{*}{ الخبرة } \\
\hline & & ${ }^{*},, Y \varepsilon$ & $T, 9 \varepsilon$ & $1 .-7$ & \\
\hline & *.,YK- &., .1 & $r, 17$ & . أفأكثر. & \\
\hline
\end{tabular}

* دالة عند مستوى الدلالة .(0,05

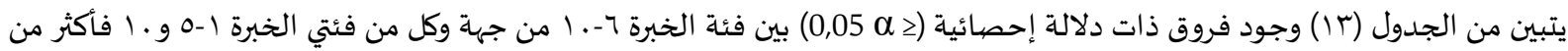

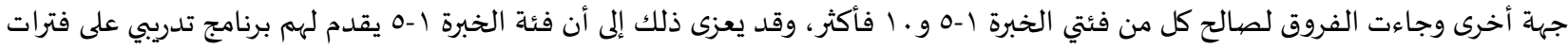

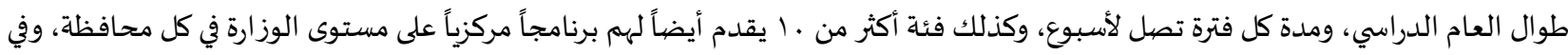

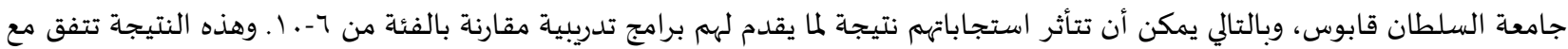

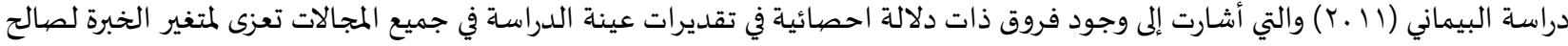

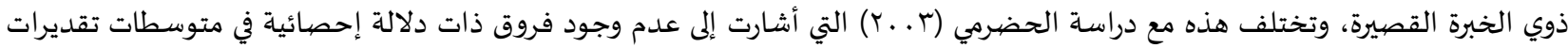

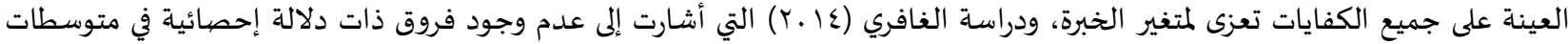
تقديرات العينة على جميع المجالات تعزى لمتغير الخبرة. ثانياً: متغير المسبى الوظيفي

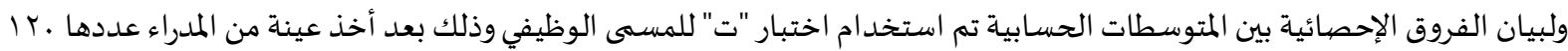
مديرا لغايات التناسب، والجداول أدناه توضح ذلك.

جدول (ع () : المتوسطات الحسابية والانحر افات المعيارية واختبار"ت" لمتغير المسسى الوظيفي على درجة تقديرات المشرفين والمديرين

\begin{tabular}{|c|c|c|c|c|c|c|}
\hline الدلالة الإحصائية & درجات الحرية & قيمة "ت" & الانحراف المعياري & المتوسط الحسابي & العدد & الوظيفة \\
\hline.,$\ldots$ & 171 & $11,11$. &.,$T V T$ & $\varepsilon, Y \uparrow$ & $\varepsilon r$ & مشرف إداري \\
\hline & & & ( & $r, .$. & IT. & مدير مدرسة \\
\hline
\end{tabular}

يتبين من الجدول (ع ا ) وجود فروق ذات دلالة إحصائية (20 0,05)تعزى لمتغير الوظيفة وجاءت الفروق لصالح المشرف الإداري. وقد يعزى ذلك إلى قيام المشرفين الإداريين بمجموعة من المهام والممارسات التي قد تكون بعيدة عن أعين المديرين وبالتالي قلة قدرة المديرين على التقييم الدقيق

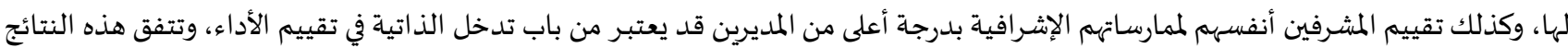
جزئيا مع دراسة (حمدان، ه . . التي أظهرت وجود فروق بين متوسط تقديرات المشرفين والمديرين لدور المشرف الإداري في تطوير الإدارة المدرسية

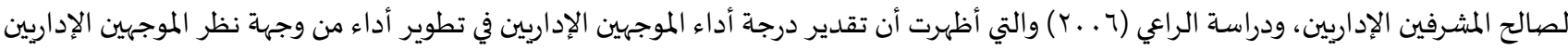

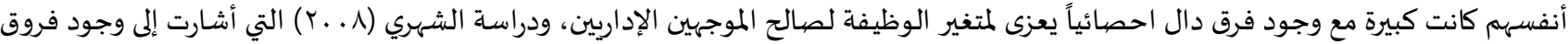

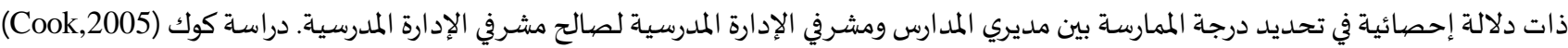

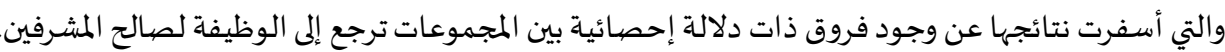

السؤال الثالث: ما الإجراءات المقترحة لتطوير الممارسات الإشرافية للمشرفين الإداريين بسلطنة عمان في ضوء مبادئ الجودة الشاملة؟

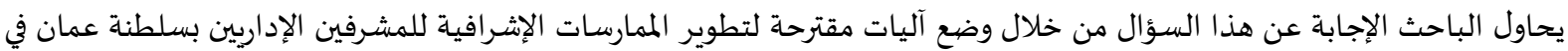

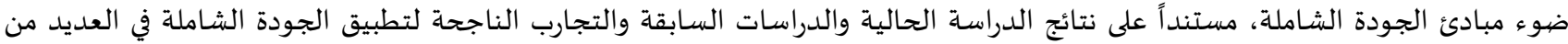

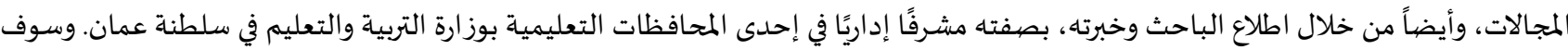

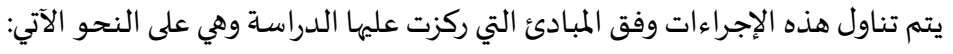
المبدأ الأول: التركيزعلى الكادر الإداري:

أ- تنطلق فلسفة الجودة الشاملة في التعليم من أهمية التركيز على المستفيدين من العملية التعليمية التعلمية وإشباع حاجاتهم وتلبية

رغباتهم، وعليه فلا بد من تحقيق ما يلي:

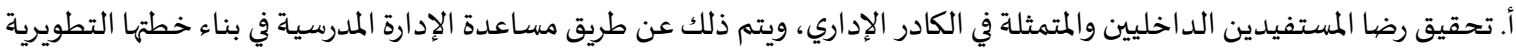
السنوية وتسهيل تنفيذها ومتابعتها على مدار العام الدراسي، وبناء علاقة تقوم على الاحترام والتقدير والثقة مع الإدارة المدرسية، ومشاركة

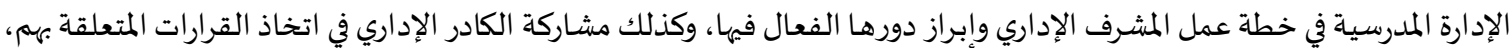
خصوصياً شواغر الترقية لوظائف أعلى، وتنقلاتهم. 
ب- تحقيق رضا المستفيدين الخارجيين وهم أولياء الأمور والمجتمع المحلي ويتم ذلك عن طريق إشراك أولياء الأمور والمجتمع المحلي في عمليات

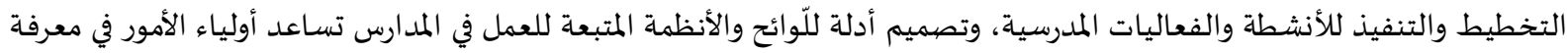
النظام المتبع في التعليم، والتخطيط المشترك لاستثمار مصادر البيئة المحلية في خدمة التعليم، وحث أولياء الأمور والمجتمع المحلي على المشاركة الفاعلة في المجالس والأنشطة المدرسية، اتباع نظام تواصلي فعال مع أولياء الأمور والمجتمع المحلي لمتابعة العملية التعليمية كالبريد

الإلكتروني مثلا.

ج- المعرفة بالقوانين الإدارية وكيفية تطبيقها: وتقع المسئولية على المشرف الإداري للتأكد من امتلاك الكادر الإداري للمفاهيم والمعرفة بالقوانين والأنظمة التي يعلمها وكيفية تطبيقها، والعمل على تحديث الإديث معلوماتهاته القانونية باستمرار.

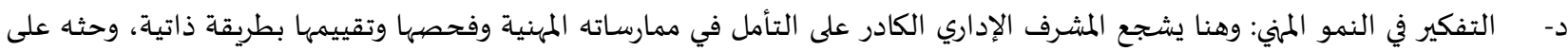

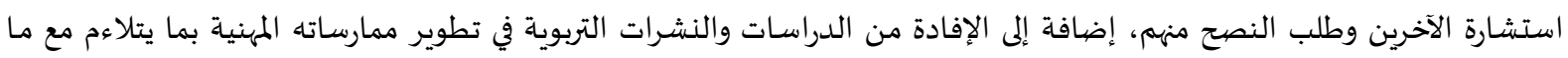

يستجد من أفكار ومكتشفات، والسعي لاستثمار إمكانات المدرسة ومصادر التعلم المختلفة في البيئة المحلية لإثراء مهاراته المختلفة.

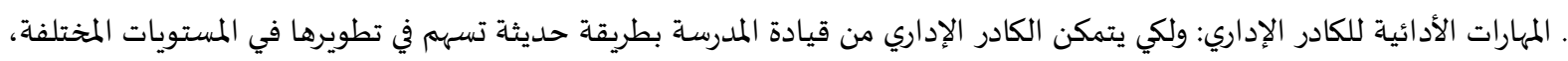

ينبغي على المشرف الإداري مساعدته وتوجيها نحو امتلاك العديد من المهارات الأدائية والتمكن منها

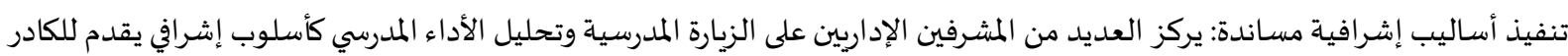

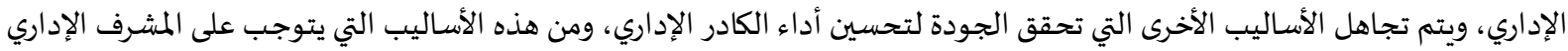

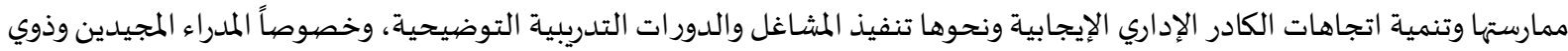
الخبرة، تنفيذ البحوث الإجرائية التي من خلالها يمكن إيجاد الحلول المناسبة للكثير من المشكلات التعليمية والسلوكية، وتبادل الزيارات

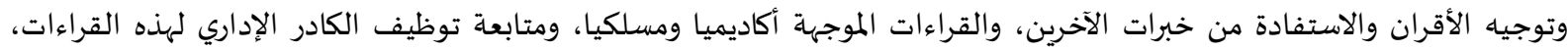

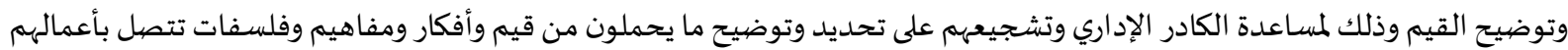

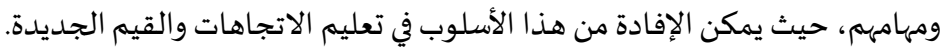

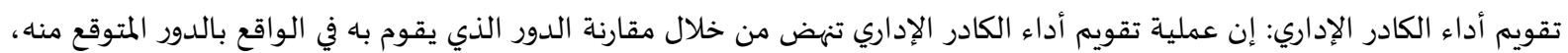

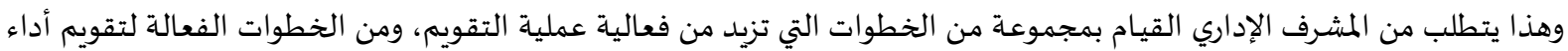
الكادر الإداري هي دراسة المعايير الموضوعة من قبل الوزارة، وإبلاغ الكادر الإداري بالمعايير في بداية العام الدراسي، ولدئ وقياس أداء الداء الكادر

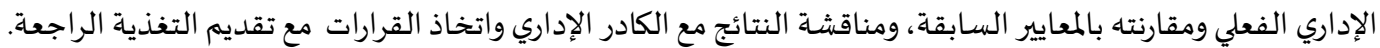

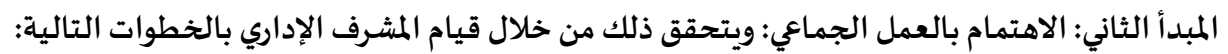

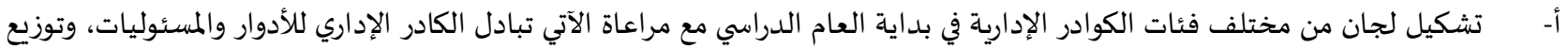

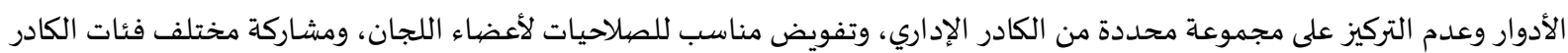
الإداري الفعالة في أنشطة هذه اللجان. تشكيل فرق المهمات من المعلمين للقيام بتنفيذ المهمات التالية: تحليل الأنشطة والفعاليات المنفذة في المدارس وإثراؤها، وإعداد النشاطات الإشرافية المختلفة وتنسيقها (نشرات، ندوات، محاضرات،....)، وتوظيف أساليب جماعية في الإشراف داخل المدرسة الواحدة والمحافظة

التعليمية.

المبدأ الثالث: القيادة التربوية الفعالة: لتحقيق الجودة الشـاملة في الإشـراف الإداري لا من وجود قيادة تربوية فعالة، تعطي اهتماماً عالياً لكل من العمل والإنتاج، كما تولي اهتماماً

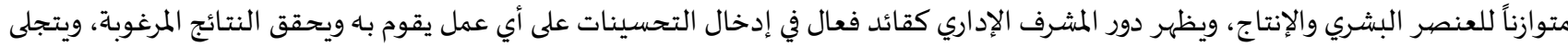

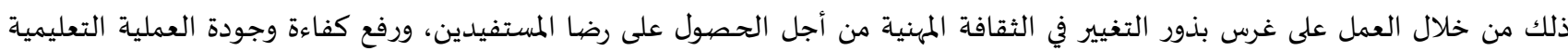
التعلمية، والعمل على تطوير المدرسة من خلال العمل على تحقيق رؤيتها ورسالتها، وتشجيع الكادر الإداري على تفويض الصايلاحيات، وتشجيع الكادر

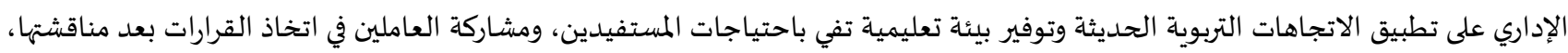
وتقبل آرائهم واحترامها.

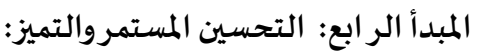
إن عملية التحسين المستمر تعنى بكافة مجالات العمل وصيولا إلى التفوق والتميز، وتتضمن ممارسات المشرف الإداري في هذا الإطار القيام 
أ- فيما يخص الكادر الإداري القيام بتشجيع الكادر الإداري على الارتقاء بمستواهم الأكاديمي ورفع مؤهلاتهم العلمية، ومسـاعدة الكادر الإداري

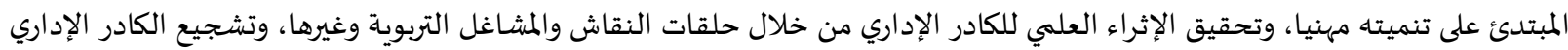

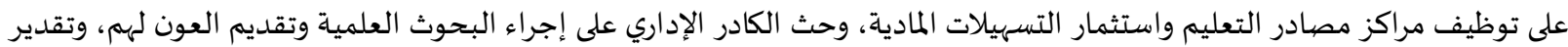

جهود الكادر الإداري المجيدين وإظهار ذلك أمام زملائهم، وتشجيع العمل الجماعي بين الكادر الإداري، والتقويم الموضيوعي للكادر الإداري. فيما يخص المدرسة يتم من خلال توفير الإمكانات اللازمة للمختبرات ولاستخدام الوسائل والتقنيات التربوية، ومتابعة تفعيل توظيف مختبر الحاسوب في تعليم التلاميذ، وتشجيع الكادر الإداري على تبني أساليب إدارية حديثة، وتطوير نظم الامتحانات المدرسية والماتية وأساليب تقويم

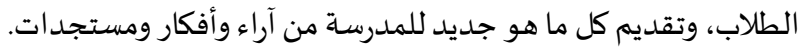

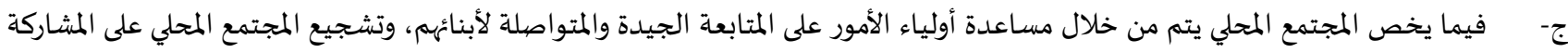
في النشاطات المدرسية ودعمها، وبناء جسور الثقة بين مختلف فئات المدارس مع بعضهم البعض، ويشجع وينظم زيارات مع مديري المدارس والمؤسسات المجاورة.

\section{توصيات الدراسـة: \\ في ضوء النتائج التي توصلت إليها الدراسـة، أوصىى الباحث بالآتي:}

ا. تكثيف الدورات التدريبية للمشرفين الإداريين في المجالات التي تناولها الدراسة لتطوير الممارسات الإشرافية للمشرفين الإدارين وربها

بالجودة الشاملة.

Y. حصر الاحتياجات التدريبية للمشرفين الإداريين من قبل المشرف الإداري الأول سنويا، والحرص على تلبية هذه الاحتياجات بدورات تدريبية مناسبة قدر الإمكان.

r. الاستفادة من البرامج التدريبية المقترحة لتطوير الكفايات الأساسية للمشرفين الإداريين في السلطنة التي تم بناؤها في مختلف دراسات الماجستير والدكتور اه في الجامعات سواء داخل السلطنة أو خارجها في الممارسات الإشرافية.

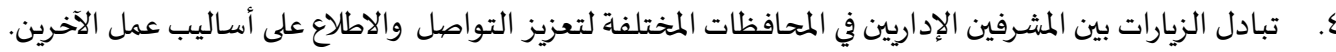
0. زيادة عدد المشرفين الإداريين وتخفيف نصابهم من المدارس التي يشرفون عليها حتى يكونون قادرين على القيام بأدوارهم بصيورة أفضل.

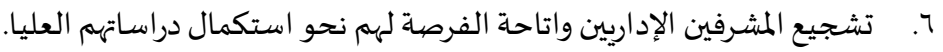

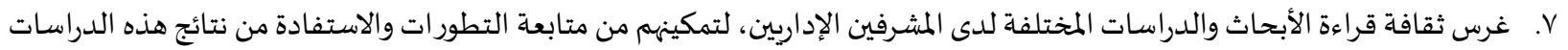
في تجويد العمل الإشرافي.

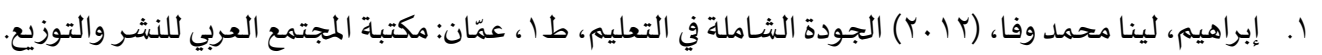
r. البيماني، كاذية بنت علي، (1 إ. Y) دور المشرفين الإداريين في تفعيل نظام تطوير الأداء المدرسي في سلطنة عمان. رسالة ماجستير غير منشورة، جامعة نزوى، سلطنة عمان.

r. الحبسي، علي بن سعيد، (1ا ــ) درجة فاعلية المشرف الإداري في تطوير أداء مديري مدارس التعليم الأسـاسي ومساعديهم بمحافظة مسقط، رسالة ماجستير غير منشورة، جامعة مؤتة، الأردن.

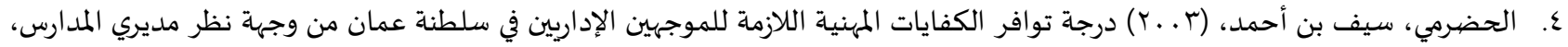
رسالة ماجستير غير منشورة، جامعة اليرموك، الأردن. 0. حمد ان، سناء سالم، (ه. . ب) دور المشرف التربوي في تطوير الإدارة المدرسية في المرحلة الأساسية الدنيا بمحافظات غزة من وجهاة نظر المشرفين التربويين والمديرين، رسالة ماجستير غير منشورة، الجامعة الإسلامية، غزة المان.

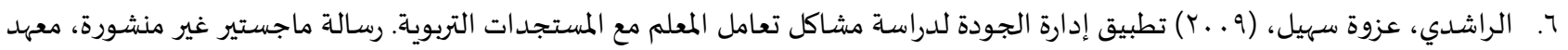
الانتاجية والجودة، الأكاديمية العربية للعلوم والتكنولوجيا والنقل البحري، جمهورية الدوردية مصرد العربية.

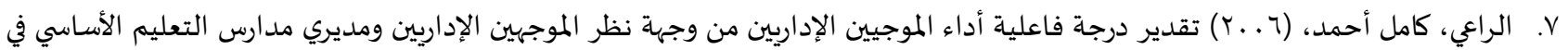
سلطنة عمان. رسالة ماجستير غير منشورة، جامعة اليرموك، المملكة الأردنية الهاشمية. 


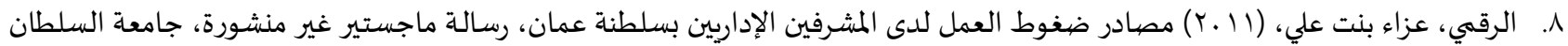
قابوس، سلطنة عمان.

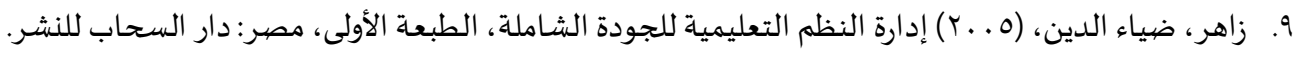

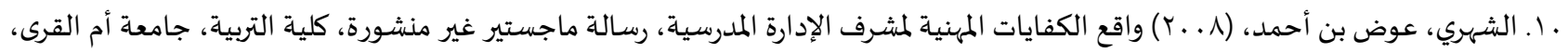
المملكة العربية السعودية.

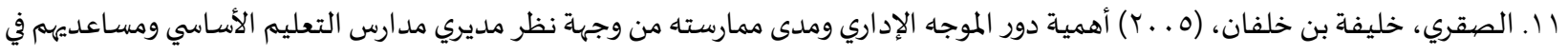

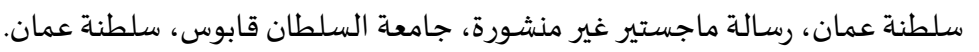

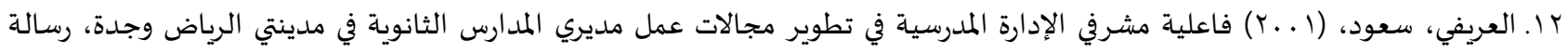
ماجستير غير منشورة، جامعة الملك سعود، المملكة العربية السعودية. ץ ا. العويسي، رجب بن علي، (7 . . ب) تطوير إدارة المدرسة الثانوية بسلطنة عمان في ضوء معايير الجودة الشاملة، رسالة دكتوراه غير منشورة. مركز

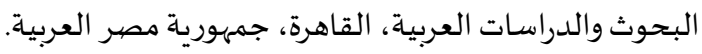
ع ا ـ الغافري، وضحاء بنت علي، (ع ا ـ ) دور المشرفين الإداريين في التنمية المهنية لمدري مدارس التعليم الأساسي بمحافظة الظاهرة في سلطنة عمان،

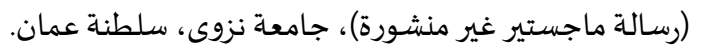

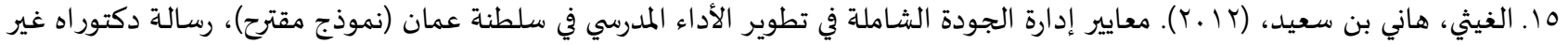
منشورة، كلية العلوم الإنسانية والاجتماعية، جامعة تونس، الجيد، الجمهورية التونسية.

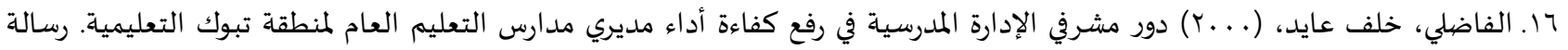
ماجستير غير منشورة، جامعة أم القرى، المملكة العربية السعودية.

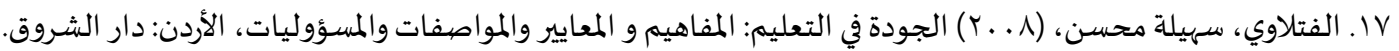

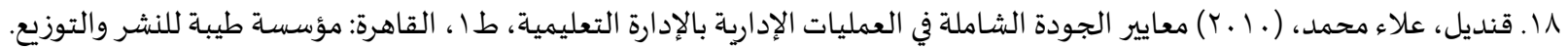

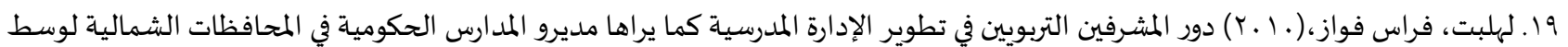

فلسطين، رسالة ماجستير غير منشورة، جامعة النجاح الوطنية، فلسطين.

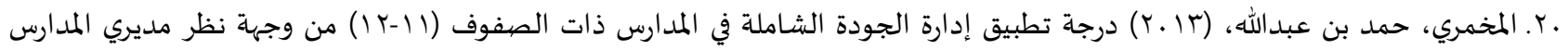
والمعلمين في محافظتي شمال الباطنة وجنوب الباطنة، رسالة ماجستير غير منشورة، جامعة مؤتة، المملكة الأردنية الهاشمياة.

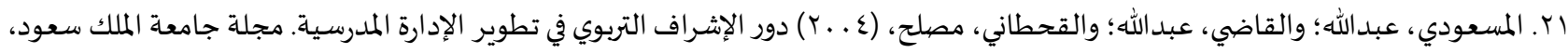

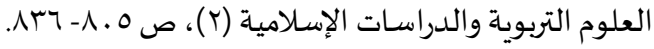

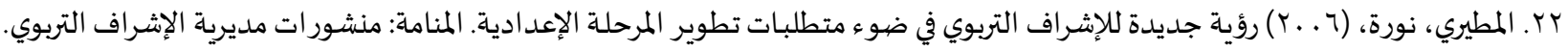
بr. معهد اليونيسكو للإحصاء ،(9 ـ . (Y) دليل لقياس تكنولوجيا المعلومات والاتصالات في التعليم. معهد اليونسكو للإحصياء، كندا.

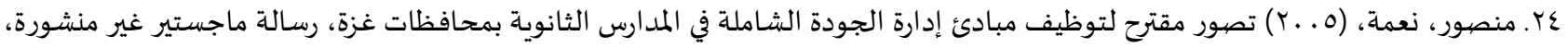
الجـامعة الإسلامية، غزة.

هr. نشوان، جميل، (ع . .ب) تطوير كفايات المشرفين الأكاديميين في التعليم الجامعي في ضوء مفهوم إدارة الجودة الشاملة في فلسطين، مجلة

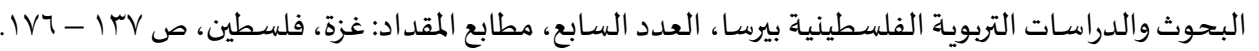
جr. النوح، عبد العزيز بن سالم، (1 . .ب) مهام مشرفي الإدارة المدرسة ومدى ممارستهم لها كما يراها مشرفو الإدارة المدرسية ومديرو المدارس الثانوية والمتوسطة بمدينة الرياض، رسالة ماجستير غير منشورة، جامعة الملك سعود، المملكة العربية السعودية. VV

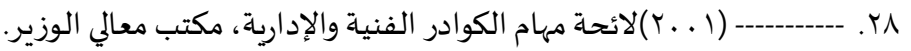

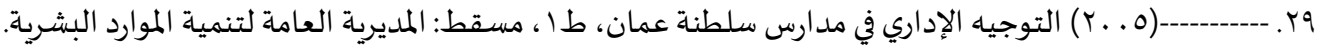

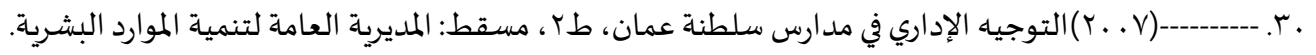

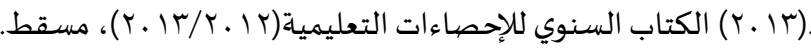
.$r$ 


$$
\text { ثانياً: المراجع الأجنبية: }
$$

[1] Alger. C., \& Chizhik. A., The reality of supervisory practices exercised by supervisors in the schools administrators Michigan State from the viewpoint of teachers. Research in Science Education, 22(1), (2006)

[2] Chizhik. A, The reality of the administrative supervision as he sees all of the supervisor and the secondary school teacher, International Journal of Educational Research, 33(2005)

[3] Cook. P. F., A survey of the views of mentors and school administrators and teachers about the administrative guidance system applied in the newly Scotland, International Journal of Science Education,25(9)(2005)

[4] Mosimann.P. \& Dussault. M., Proven strategies for turning information into higher business performance, The performance Manager, (2007)

[5] Nany. D. \&Yendol. S. D., Obstacles administrative supervision as perceived by supervisors and supervisors in the city of Toronto, Canada, Journal of Research in Science Teaching, 45(3)(2007)

[6] Reeves. D, Looking deeper into the data, Educational Leadership, 66(2009),4 p89-90.

[7] Snyder. Jack, Administrative supervision requirements to achieve educational quality, Educational Psychologist, 30(4)(2005).

[8] Tir. Jaroslav., Lack of administrative supervision in schools actually and treatment, Information on Education, 37(1)(January 2002) 


\section{Developing the Practice of Administrative Supervisors in the Ministry of Education in the Sultanate of Oman in the Light of the Total Quality Principles}

\section{Zayid khalifa Mohammed Almoqbali}

Educational Foundations and Administration Department- College of education- sultan Qaboos university-

Sultanate of Oman

zayd.almuqbali@moe.om

Abstract: $\quad$ This study aimed to develop the practice of administrative supervisors in the Ministry of Education in the Sultanate of Oman in the light of the total quality principles through studying the requirements of being an administrative supervisor in Oman from perspectives of administrative supervisors and school principals, and through finding out the differences among the individuals of the study sample in estimating the level of administrative supervisors' practices in Oman in the light of the total quality principles. These differences attributed to governorate, experience, gender, and job title variables.

In order to achieve the study's goals, a questionnaire was developed which consisted of two sections. The first section consisted of basic personal information which was educational governorate, experience, gender, and academic qualification; whereas the second section consisted of 38 items categorized into four principles in order to find out the supervisory practices of administrative supervisors in Oman in the light of the total quality principles. The questionnaire was applied on a sample of 599 male and female school principals, and administrative supervisors after investigating the validity and reliability of it. The data was analyzed by using the statistical package of social sciences (SPSS) through several statistical methods.

The study led to many findings as follows:

1. The degree of estimating the individuals of the supervisory practices in the light of the total quality was medium.

2. There were statistical differences attributed to the governorate variable, and the posteriori comparisons were used to show the statistical pair differences between the statistical averages. They were in favor of south Al-Batinah Governorate.

3. There were statistical differences attributed to the gender variable in favor of males.

4. There were also statistical differences attributed to the experience variable, and the posteriori comparisons were used to show the statistical pair differences between statistical averages. They were in favor of the categories: 1-5, and more than 10 years of experience.

5. There were statistical differences attributed to the job tittle variable in favor of administrative supervisors.

According to the study findings, some procedures were suggested to develop the supervisory practicing in Oman in the light of total quality principles, and they were presented in a separate chapter (chapter 7). Furthermore, the study suggested some future studies to be carried out on this subject.

Keywords: Supervisors, Sultanate of Oman, Total Quality. 


\section{References:}

[1] Abrạhym. Lynạ Mḥmd Wfạ, Ạljwdh Ạlshạmlh Fy Ạlt'lym, Ṭ1, 'mạn: Mktbẹ Ạlmjtm` Ạl'rby Llnsḥr Wạltwzy', (2012)

[2] Ạl'ryfy. S`wd, Fạ lÿ̈ Msḥrfy Ạlạdạrh Ạlmdrsyh Fy Tțwyr Mjạlạt 'ml Mdyry Ạlmdạrs Ạlthạanwyh Fy

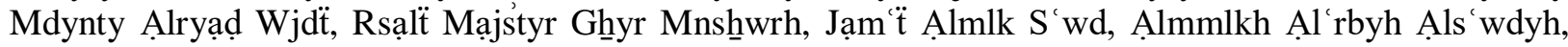
(2001)

[3] Ạl'wysy. Rjb Bn 'ly, Tțwyr Ạdạrt Ạlmdrsh Ạltḥạnwyh Bslṭnt 'mạn Fy Dw’ M'ạyyr Aljwdh Ạlshạamlh, Rsạlẗ Dktwrạh Ghyyr Mnshwwrh. Mrkz Ạlbḥwth Wạldrạsạt Ạl'rbyh, Ạlqạhrh, Jmhwrÿ̈ Mṣr Ạl'rbyh, (2006)

[4] Ạlbymạny. Kạdḩyh Bnt 'ly, Dwr Ạlmshrrfyn ẠlạDạryyn Fy Tf'yl Nzạm Tṭwyr Ạlạ̉dạ' Ạlmdrsy Fy Slṭnẗ

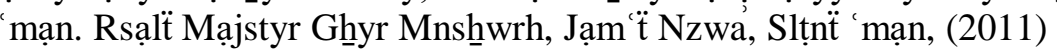

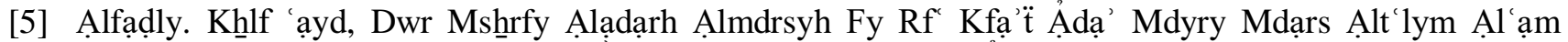
Lmnṭä Tbwk Ạlt'lymyh. Rsạlt Mạjstyr Ghyr Mnshwwrh, Jạm ‘̈ Ạm Ạlqry, Ạlmmlkh Ạl'rbyh Ạls'wdyh, (2000)

[6] Ạlftlạwy. Shylh Mḥsn, Ạljwdh Fy Ạlt lym: Ạlmfạhym W Ạlm ’ạyyr Wạlmwạṣạt Wạlmsw̉wlyạt, Ạlạ̉rdn: Dạr Alshhrwq, (2008)

[7] Alger. C., \& Chizhik. A., The reality of supervisory practices exercised by supervisors in the schools administrators Michigan State from the viewpoint of teachers. Research in Science Education, 22(1), (2006)

[8] Ạlghạafry. Wḍhạa Bnt 'ly, Dwr Ạlmsḥrfyn ẠlạDạryyn Fy Ạltnmyh Ạlmhnyh Lmdry Mdạrs Ạlt'lym

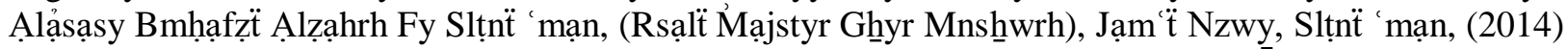

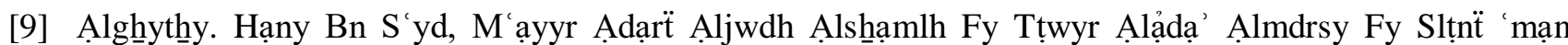

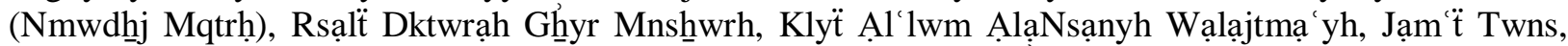
Ạljmhwryh Ạltwnsyh, (2012)

[10] Ạlḥbsy. 'ly Bn S'yd, Drjë Fạ lyë Ạlmsḥrf Ạlạdạry Fy Tțwyr Ạ̉dạ' Mdyry Mdạrs Ạlt'lym Ạlạ̉sạsy Wmsạ dyhm Bmhạfặ Msqț, Rsạlẗ Mạjstyr Ghyr Mnshnwrh, Jạm ‘̈ Mw̉th, Ạlạ̉rdn, (2011)

[11] Ạlhụrmy. Syf Bn Ạ̉hmd, Drjë Twạfr Ạlkfạyạt Ạlmhnyh Ạllạzmh Llmwjhyn ẠlạDạryyn Fy Slṭnẗ 'mạn Mn Wjḧ̈ Nẓr Mdyry Ạlmdạrs, Rsạlẗ Mạjstyr Ghyr Mnshwwrh, Jạm ‘̈ Ạlyrmwk, Ạlạ̉rdn, (2003)

[12] Ạlmkhmry. Ḥmd Bn 'bdạllh, Drjë Tṭbyq ADạrẗ Ạljwdh Ạlshạamlh Fy Ạlmdạrs Dhạt Ạlṣfwf (11-12) Mn Wjhẗ Nẓr Mdyry Ạlmdạrs Wạlm lmyn Fy Mhạazțty Shmạl Ạlbạtnh Wjnwb Ạlbạṭnh, Rsạlẗ Mạjstyr Ghyr

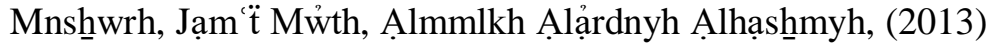

[13] Ạlms 'wdy. 'bdạllh, ạlqạdy. 'bdạllh \& ạlqhṭạny, Mṣlḥ, Dwr ẠlạShbrạf Ạltrbwy Fy Tțwyr Ạlạdạrh Ạlmdrsyh. Mjlẗ Jạm ‘̈ Ạlmlk S'wd, Ạl'lwm Ạltrbwyh Wạldrạsạt ẠlạiSlạmyh (2)(2004), pp.805- 836.

[14] Ạlmțyry. Nwrh, Rw̉yh Jdydh LlạShrậf Altrbwy Fy Ḍ̂’ Mtṭlbạt Tṭwyr Ạlmrḥlh Ạlạ dạdyh. Ạlmnạmh: Mnsh̆wrạt Mdyryt ẠlậShrạf Ạltrb̧wy, (2006)

[15] Ạlnwḥ. 'bdạl zyz Bn Sạlm, Mhạm Msḥrfy Ạlạdạrh Ạlmdrsh Wmda Mmạrsthm Lhạ Kmạ Yrạhạ Mshrfww Ạlạdạrh Ạlmdrsyh Wmdyrw Ạlmdạrs Ạlthạnwyh Wạlmtwsṭh Bmdynẗ Ạlryạḍ, Rsạlẗ Mạjstyr Ghyr

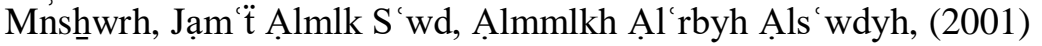


[16] Ạlrạ 'y. Kạml Ạ̉ḥmd, Tqdyr Drjë Fạ 'lÿ̈ Ạdạ’ Ạlmwjyyn Ạlạdạryyn Mn Wjhë Nẓr Ạlmwjhyn Ạlạdạryyn

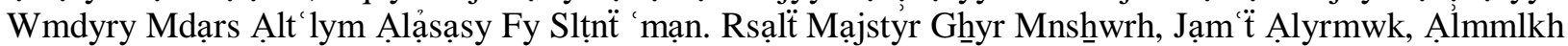
Ạlạ̉rdnyh Ạlhạshnmyh, (2006)

[17] Ạlrạshhdy. 'zwë Shyl, Tṭbyq Adạrẗ Ạljwdh Ldrạsë Mshạkl T’ạml Ạlm'lm M'Ạlmstjdạt Ạltrbwyh. Rsạlẗ Mạjstyr Ghyr Mnshwwrh, M'hd Ạlạntạjyh Wạljwdh, Ạlạkkạdymyh Ạl'rbyh Ll'lwm Wạltknwlwjyạ Wạlnql Ạlbḥry, Jmhwryẗ Mṣr Ạl'rbyh, (2009)

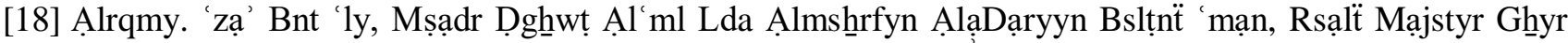
Mnsh́wrh, Jạm ‘̈ Ạlslțạn Qạbws, Slțnè ‘mạn, (2011)

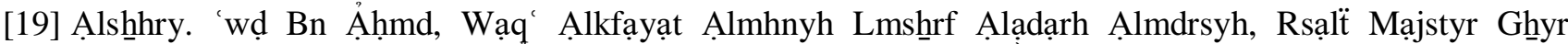

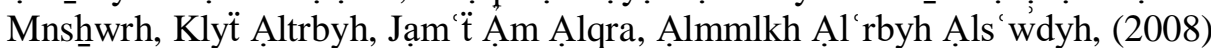

[20] Alṣ̣qry. Khllyft Bn Khllfạn, Ạhmÿ̈ Dwr Ạlmwjh ẠlạDạry Wmdy Mmạrsth Mn Wjhẗ Nẓr Mdyry Mdạrs

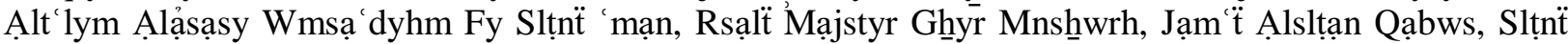
'mạn, (2005)

[21] Chizhik. A, The reality of the administrative supervision as he sees all of the supervisor and the secondary school teacher, International Journal of Educational Research, 33(2005)

[22] Cook. P. F., A survey of the views of mentors and school administrators and teachers about the administrative guidance system applied in the newly Scotland, International Journal of Science Education,25(9)(2005)

[23] Ḥmdạn. Snạ’ Sạlm, Dwr Ạlmsḥrf Ạltrbwy Fy Tțwyr Ạlạdạrh Ạlmdrsyh Fy Ạlmrḥlh Ạlạ̉sạsyh Ạldnyạ

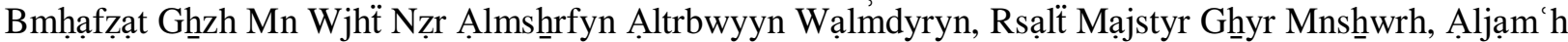
ẠlạSlạmyh, Ghzh, (2005)

[24] Lhlbt. Frạs Fwạz, Dwr Ạlmsḥrfyn Ạltrbwyyn Fy Tțwyr ẠlạDạrh Ạlmdrsyh Kmạ Yrạhạ Mdyrw Ạlmdạrs

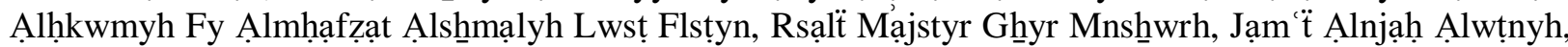
Flsțn, (2010)

[25] M'hd Ạlywnyskw Llậ̣ṣạ' , Dlyl Lqyạs Tknwlwjyạ Ạlm lwmạt Wạlạtṣạlạt Fy Ạlt 'lym. M'hd Ạlywnskw Llậ̣̦̣ạa', Kndạ, (2009)

[26] Mnșwr. N‘mh, Tṣwr Mqtrḥ Ltwzyf Mbạdỷ Adạrẗ Ạljwdh Ạlsḥạmlh Fy Ạlmdạrs Ạlthạanwyh Bmhạạạat

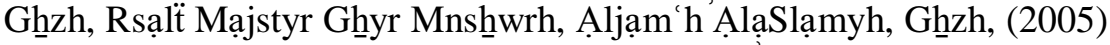

[27] Mosimann.P. \& Dussault. M., Proven strategies for turning information into higher business performance, The performance Manager, (2007)

[28] Nany. D. \&Yendol. S. D., Obstacles administrative supervision as perceived by supervisors and supervisors in the city of Toronto, Canada, Journal of Research in Science Teaching, 45(3)(2007)

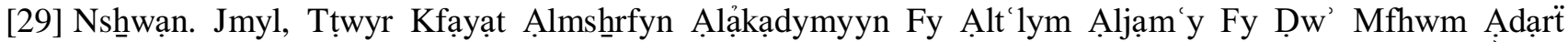
Ạljwdh Ạlshạmlh Fy Flsțyn, Mjl̈̈ Ạlbḥwth Wạldrạsạt Ạltrbwyh Ạlflsțynyh Byrsạ, Mțạb Ạlmqdạd: Ghzh, Flsṭyn, (7)(2004),pp. 137-176.

[30] Qndyl. 'lạ’ Mḥmd, M'ạyyr Ạljwdh Ạlsḥạmlh Fy Ạl'mlyạt ẠlạDạryh Bạlạdạrh Ạlt lymyh, Ṭ1, Ạlqạhrh: Mw̉ssẗ Țybh Llnshr Wạltwzy', (2010)

[31] Reeves. D, Looking deeper into the data, Educational Leadership, 66(2009),4 p89-90.

[32] Snyder. Jack, Administrative supervision requirements to achieve educational quality, Educational Psychologist, 30(4)(2005). 
[33] Tir. Jaroslav., Lack of administrative supervision in schools actually and treatment, Information on Education, 37(1)(January 2002)

[34] Wzạrẗ Ạltrbyh Wạlt' lym, Ạlt lym Ạlạ̉sạsy Fy Slțn̈ 'mạn, Msqț, (1999)

[35] Zạhr. Dyạ’ Ạldyn, ẠDạrt Ạlnẓm Ạlt 'lymyh Lljwdh Ạlsḥạmlh, Ạlț̣ 'h Ạlạ̉wla, Mṣr: Dạr Ạlsḥạb Llnsḥr, (2005)

[36] ----------Ạlktạb Ạlsnwy Llạhṣạa ạt Ạlt 'lymyh, Msqț, (2013)

[37] ----------Ạltwjyh ẠlạDạry Fy Mdạrs Slṭnẗ 'mạn, Ṭ1, Msqț: Ạlmdyryh Ạl'ạmh Ltnmÿ̈ Ạlmwạrd Ạlbshryh, (2005)

[38] ---------Ạltwjyh ẠlạDạry Fy Mdạrs Slțn̈ 'mạn, Ṭ2, Msqṭ: Ạlmdyryh Ạl'ạmh Ltnmÿ̈ Ạlmwạrd Ạlbshryh, (2007)

[39] ----------- Lậ̉ḥt Mhạm Ạlkwạdr Ạlfnyh Wạlạiậryh, Mktb M‘ạly Ạlwzyr, (2001) 